\section{Sedimentary}

\section{Research}

Journal of Sedimentary Research, 2008, v. 78, 512-528

Research Article

DOI: $10.2110 /$ jsr.2008.061

\title{
DYNAMICS OF A TRANSGRESSIVE PRODELTAIC SYSTEM: IMPLICATIONS FOR GEOGRAPHY AND CLIMATE WITHIN A PENNSYLVANIAN INTRACRATONIC BASIN, COLORADO, U.S.A.
}

\author{
P.M. MYROW, ${ }^{1}$ C. LUKENS, ${ }^{1}$ M.P. LAMB, ${ }^{2}$ K. HOUCK, ${ }^{3}$ AND J. STRAUSS ${ }^{1}$ \\ ${ }^{1}$ Department of Geology, Colorado College, Colorado Springs, Colorado 80903, U.S.A. \\ ${ }^{2}$ Department of Earth \& Planetary Science, University of California, Berkeley, California 94720, U.S.A. \\ ${ }^{3}$ Department of Geography and Environmental Sciences, University of Colorado, Denver, Colorado 80217-3364, U.S.A. \\ e-mail: pmyrow@coloradocollege.edu
}

\begin{abstract}
Detailed sedimentological analysis of a prodeltaic turbidite unit within the Pennsylvanian Minturn Formation provides insight into the nature of fan-delta deposition, and allows reconstruction of paleogeographic and paleoclimatic conditions within a tectonically active cratonic basin. The formation, a thick succession of fan-delta deposits, exhibits a complex stratigraphic architecture of alluvial, fluvial, and deltaic lithofacies that were deposited in the Central Colorado Basin (CCB), U.S.A., a fault-bounded depression within the Ancestral Rockies. An $\sim 20$ to 35-m-thick, regionally extensive, unconformity-bounded prodelta unit was deposited during a large eustatic sea-level rise that temporarily interrupted coarsegrained fluvial-deltaic deposition. The unit consists of dark-green shale and sandstone event beds with tool marks produced by abundant plant debris. The sandstone event beds were previously interpreted as turbidites because they contain current ripples, parallel lamination, and sole marks consistent with deposition from turbidity currents in the absence of storm-generated surface gravity waves. We have found, however, that proximal prodeltaic deposits contain evidence for combined oscillatory and unidirectional flow (i.e., asymmetric hummocky cross stratification (HCS), quasi-planar lamination, and combined-flow ripple stratification), indicating deposition under large waves in relatively shallow water. Paleohydraulic calculations indicate that formation of the HCS beds requires a fetch of at least $75 \mathrm{~km}$ to generate the necessary wave periods. Given the position of the CCB in the lee of the ancestral Front Range relative to the prevailing trade winds, and the narrow seaway to the south, storms either tracked across the Cordilleran seaway from the west or formed in situ within the CCB. The former hypothesis is consistent with paleoclimate models that purport the development of summer monsoonal circulation patterns over western equatorial Pangea during the late Paleozoic, and regional observations of southeastward eolian bedform migration directions.
\end{abstract}

\section{INTRODUCTION}

Although ancient turbidites have been extensively studied from deep-sea lithofacies, much less is known about ancient or modern prodeltaic turbidites. Deltaic deposits are complex and can reflect the combined effects of climate, sea level, tectonics, and sediment supply (e.g., Nittrouer et al. 1996; Pirmez et al. 1998; Posamentier and Allen 1999; Paola 2000; Swenson et al. 2005). The signal of such processes is generally strong for fan deltas in tectonically active fault-bounded basins because of the short distance between sediment sources in uplands and their depositional sinks (e.g., Mulder and Syvitski 1995). Depositional processes for fan deltas can include sediment transport by river plumes, ocean currents, storm waves, and sediment gravity flows (Nittrouer and Wright 1994). In prodeltas, the muddy, gently sloping lower parts of deltas that extend below the delta front, much deposition takes place during river floods and storm events, and the depositional processes of the resulting event beds are key to understanding patterns of sediment distribution, and ultimately the threedimensional stratigraphy of fan-delta deposits. Proximal-distal changes in the thickness and character of storm deposits have been an important component of facies models for storm-influenced shorelines (Walker 1984; Aigner 1982, 1985; Myrow 1992). Such proximality trends are useful in paleoenvironmental and sea-level reconstructions, as well as other aspects of basin analysis. However, much of the depositional dynamics and lithofacies patterns of event beds in ancient prodeltaic environments remains unknown, including: (1) proximal to distal distribution of wavegenerated structures, (2) paleocurrent patterns, and (3) reorganization of flow patterns within evolving prodeltaic topography.

In this paper, we present a detailed sedimentological analysis of a prodelta unit in the Pennsylvanian Minturn Formation (Fig. 1). Prodelta deposits at two other localities within the Central Colorado Basin (CCB) have been interpreted as turbidites deposited below storm-wave base (Soulliere et al. 1984; Lindsey et al. 1986; Hoy and Ridgway 2002, 2003; Schenk 1986, 1989). However, we interpret the prodelta unit in our study area to have been deposited in relatively shallow water under the influence of both storm-generated waves and strong currents. We first present a detailed sedimentological analysis of the unit, including the evidence for storm waves. Second, paleohydraulic calculations are presented that constrain reconstructions of the ancient high-energy fan-delta system, including the origin of storm systems within the CCB. Finally, we discuss the implications of inferred storm paths for the ongoing debate concerning the nature of climate and atmospheric circulation within the western part of equatorial Pangea. Our findings are relevant to studies that suggest possible reversed equatorial flow (i.e., low-latitude westerlies) related to a variety of mechanisms, including enhanced summer monsoonal circulation (Gibbs et al. 2002; Tabor and Montañez 2002). 


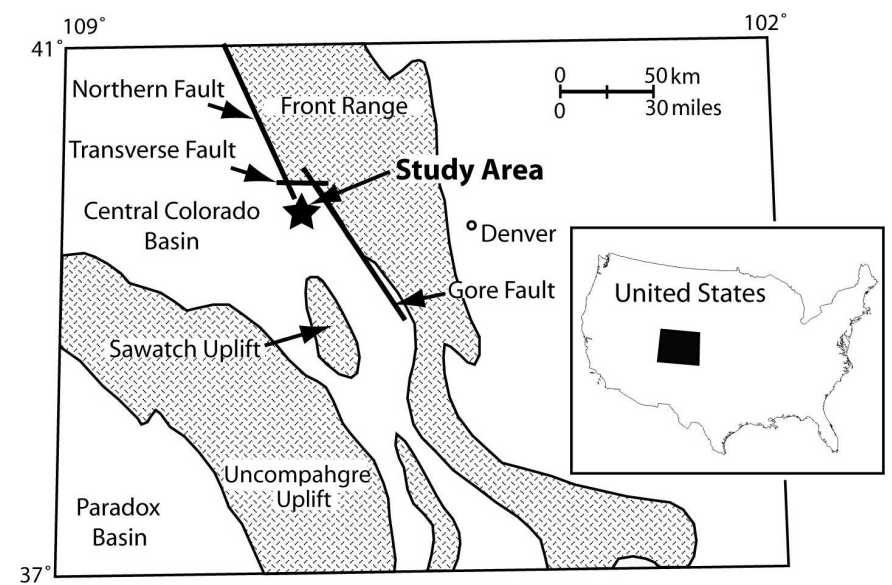

FIG. 1.- Pennsylvanian paleogeographic map of Colorado, showing uplifted areas and sedimentary basins. The location of the study area and the offset of the en echelon bounding faults on the eastern margin of the Central Colorado Basin are also shown. After Mallory (1972) and DeVoto (1980).

\section{GEOLOGIC SETTING}

The Minturn Formation was deposited along the eastern margin of the CCB during the Pennsylvanian, and sits on the western flank of the Front Range (Fig. 1). In the Pennsylvanian, the trough-shaped basin was bounded by the Ancestral Front Range to the northeast and the Uncompahgre Uplift to the southwest, which separates it from the Paradox Basin of southwest Colorado and southeast Utah (Tweto 1949). DeVoto et al. (1986) proposed that the Ancestral Sawatch uplift, developed locally in the center of the basin, was also a positive topographic feature. The study area is located $19 \mathrm{~km}$ west of the Gore Fault zone (Figs. 1, 2), and $15 \mathrm{~km}$ south of an en echelon offset, where a transverse fault truncates both the Gore Fault and an unnamed fault to the north (Fig. 1). The transverse and northern faults were inferred to have been active in the Pennsylvanian (DeVoto et al. 1986), but because the Minturn Formation is covered to the north by Mesozoic rocks, Pennsylvanian movement on the northern fault cannot be documented (Houck 1993). The Gore Fault zone was active during the Laramide Orogeny and in the Pennsylvanian (Tweto and Lovering 1977; DeVoto et al. 1986). DeVoto et al. (1986) estimated dip-slip displacement of 1525 $2135 \mathrm{~m}$ in the Desmoinesian stage alone. The amount of strike-slip movement in the Pennsylvanian is unknown (Houck 1993).

Regional paleogeographic and paleoenvironmental reconstructions (Houck 1991, 1997) indicate that sediment was dispersed from highlands in the north towards the south during deposition of the Minturn Formation, presumably from the en echelon offset of the Gore Fault (Fig. 2). Paleocurrent data from Houck (1991) come from a variety of alluvial and marine lithofacies within the Minturn Formation. At this time the exposed sediment source rocks were primarily Precambrian granite and Paleozoic sandstone units, and thus the sediment deposited in the CCB was largely arkosic (Tweto 1949; Stevens 1958; Kairo et al. 1993). Deposition was controlled in part by eustatic changes related to glaciations on Gondwanaland (Crowell 1978; Houck 1993, 1997). The Minturn is coeval with the Eagle Valley Formation and the Eagle Valley Evaporite, both of which were deposited in the central part of the basin (Schenk 1986, 1989).

\section{DEPOSITIONAL SYSTEMS}

The Minturn Formation is composed mainly of conglomerate, sandstone, and shale of both marine and nonmarine origin, and includes fluvial, delta, prodelta, foreshore, and shallow marine facies (Fig. 3).
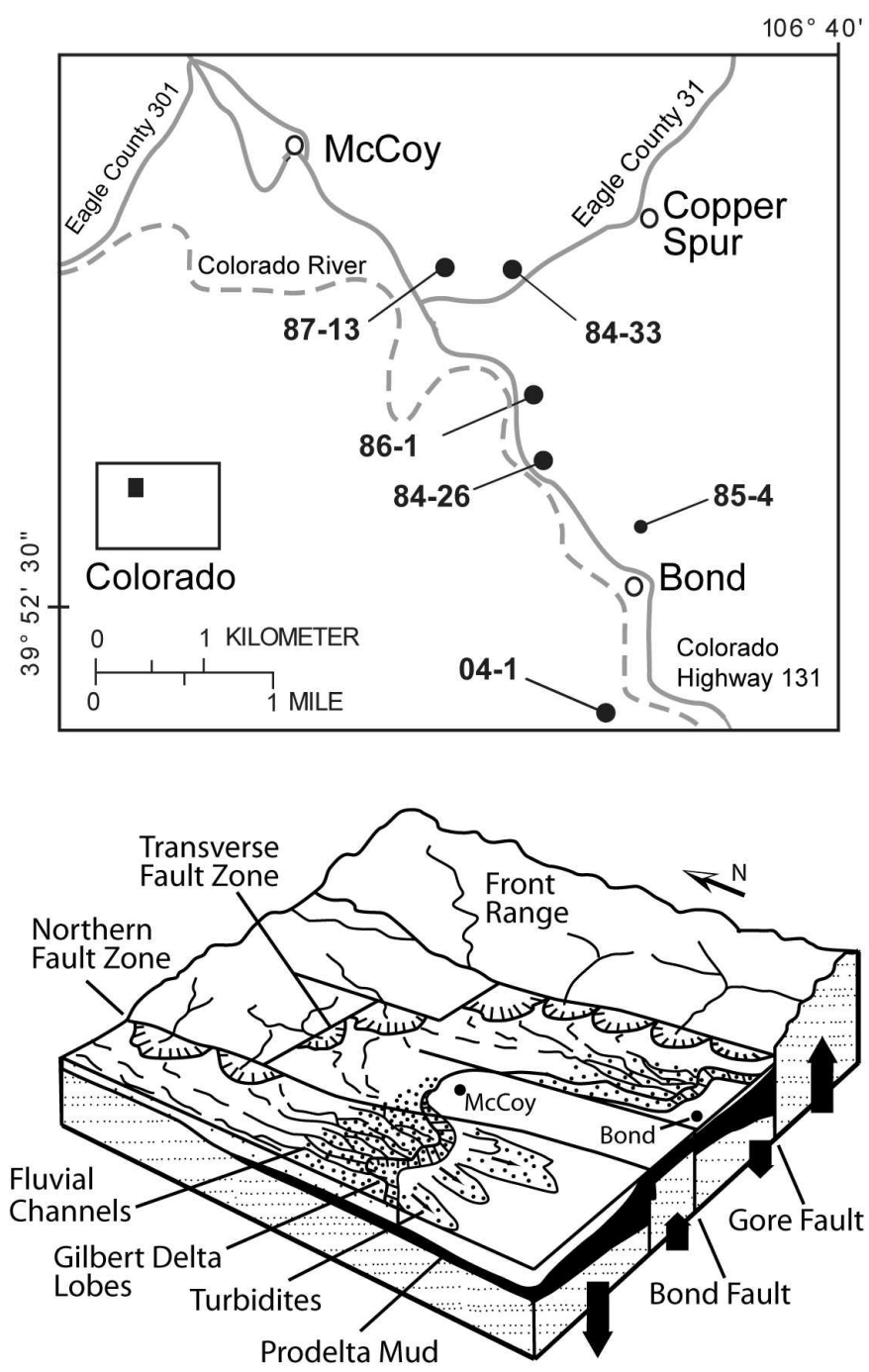

FIG. 2.-Locality map of Bond-McCoy region of Colorado. Locality numbers are from Houck (1993). Generalized paleogeographic reconstruction of the Minturn Formation depositional paleoenvironments (after Houck 1993).

Houck $(1993,1997)$ divided the middle part of the formation into nine depositional sequences that crop out over a $100 \mathrm{~km}^{2}$ region. Sequence boundaries with a few tens of meters of relief are overlain initially by braided fluvial conglomerate, and then by transgressive-systems-tract deposits of coarse sandstone that were deposited in retrogradational barrier and deltaic environments. Condensed sections composed of fossiliferous marine limestone are overlain by highstand deposits of Gilbert-type deltas made up of coarse sandstone to granule conglomerate. Isopachs of these deltaic deposits indicate that the delta lobes are generally 7-8 $\mathrm{m}$ thick and extend $<1 \mathrm{~km}^{2}$ areally. The largest lobes are $15-18 \mathrm{~m}$ thick and cover $\sim 2 \mathrm{~km}^{2}$. Entire delta complexes are at least $300 \mathrm{~m}$ thick and a minimum of $25 \mathrm{~km}^{2}$ in area.

The turbidite unit described in this study is Houck's $(1991,1993)$ unit 5a (Fig. 3) (Donner's (1949) "Walchia bed"), which was deposited during a relative sea-level rise in the early Desmoinesian. Biostratigraphic data indicate that the unit spans the Beedina apachensis, B. cedarensis, B. leei, and Wedekindellina henbesti fusulinid zones (Houck 1993), which suggests that its deposition may have coincided with the Inola transgression in the US mid-continent (Ross and Ross 1987). The turbidites are underlain by an Atokan-Desmoinesian boundary unconformity, which regionally 

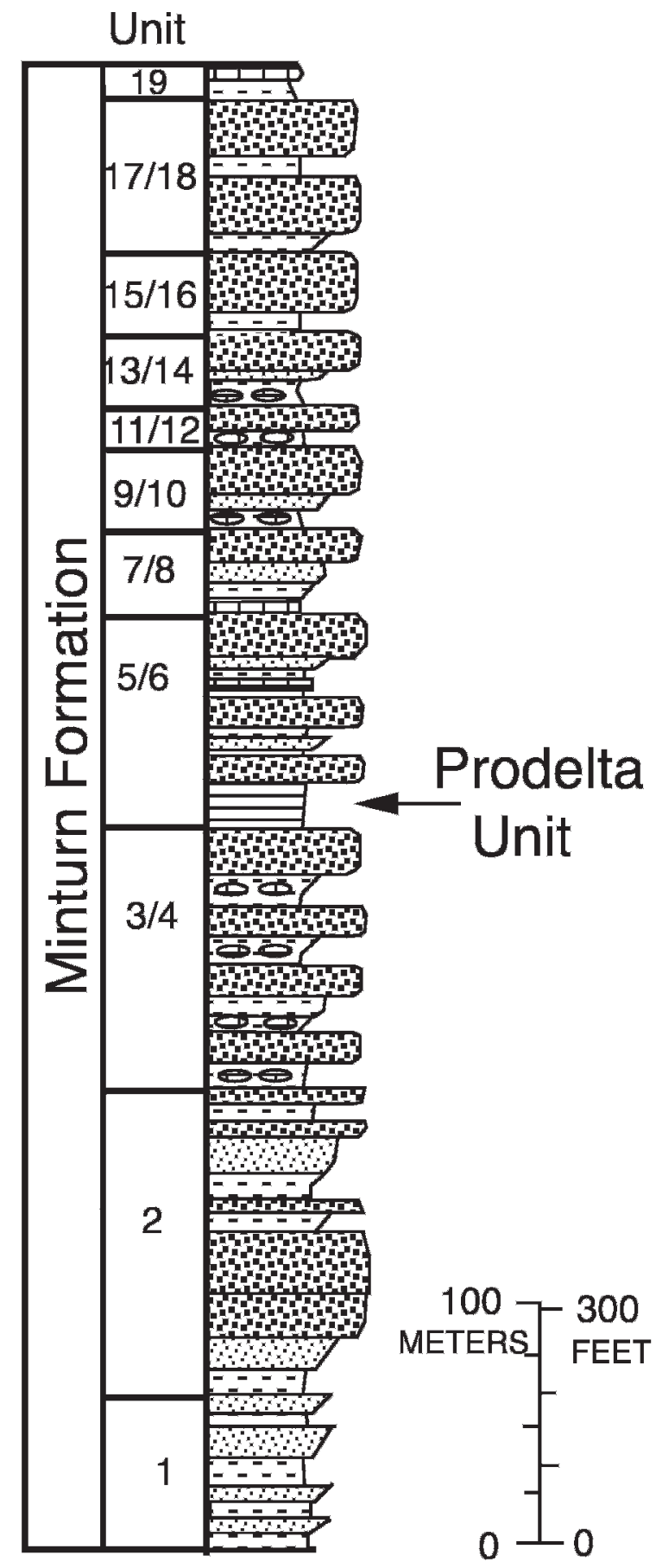

\section{LEGEND}

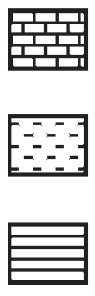

Límestone

\section{Shale}

Sandstone and Shale

shows $\sim 50-60 \mathrm{~m}$ of relief (Houck 1993). The turbidites were thought by Houck $(1993,1997)$ to have been deposited in two incised valleys located in the eastern and western parts of the study area, but there is not enough exposure to determine their precise size and geometry. The turbidite unit is everywhere shale rich, indicating that the transgressing shoreline migrated beyond the limits the field area. Time-equivalent delta-front and shoreline lithofacies, which would have been deposited in the proximal hinterland, are not preserved due to subsequent uplift and erosion (Houck 1997).

Soulliere et al. (1984), Lindsey et al. (1986), and Hoy and Ridgeway (2003, 2003) also described turbidites in the Minturn Formation from the Sangre de Cristo Mountain region in the southern part of the Central Colorado Basin. These authors interpreted the turbidites as deposits of fluvially dominated fan deltas that were deposited below storm-wave base, based on a lack of hummocky cross stratification (HCS) or other evidence of wave influence. Schenk (1986, 1989), in a study of the Eagle Valley Evaporite in the central part of the CCB, also described turbidite beds, which he interpreted as a result of deposition from below storm wave base because they lacked wave-generated sedimentary structures.

\section{PRODELTA UNIT}

The prodelta unit described in this paper crops out on the limbs of a large, south-plunging, asymmetric syncline and anticline. Detailed centimeter-scale stratigraphic sections were measured at closely spaced proximal, intermediate, and distal localities (localities 87-13 and 84-33; $86-1$; and $84-26,85-4$, and $04-1$, respectively) that are approximately aligned along the inferred sediment dispersal path (Fig. 2). The outcrops are oriented along the limbs of an anticline-syncline pair, and all but 85-4 and 04-1 are on the downthrown side of the nearby Bond Fault (Fig. 2; Houck 1993). The unit can be traced between outcrops, although individual beds cannot, because of scattered cover. There are no structural features that postdate deposition of the prodelta unit that would influence the observed depositional patterns.

The prodelta unit ranges from 18.9 to $35.3 \mathrm{~m}$ thick and consists of approximately $30 \%$ sandstone and $70 \%$ shale on average (Fig. 4A; Table 1). The strata directly below and above the unit are well exposed in many localities and range from siltstone to coarse-grained red sandstone and conglomerate (Fig. 4B). Sandstone beds in the prodelta unit range from $<2 \mathrm{~cm}$ to over a meter thick, although most are thin to medium bedded. Most event beds consist of very fine- to fine-grained sandstone, but range up to medium- to coarse-grained sandstone. The beds are light tan-gray in color, although the coarsest beds are micaceous and darker gray to brown. Plant fossils are found in all localities and are mostly gymnosperms, including Walchia (conifer), Samaropsis (gymnosperm seed), Cardiocarpus (gymnosperm seed), Callipteris (seed fern), and Odontopteris (seed fern) (Arnold 1941; Donner 1949).

The event beds of the prodelta unit display clear proximality trends over only a few kilometers (Fig. 2). Table 1 illustrates the characteristics of every event bed with a thickness greater than $3 \mathrm{~cm}$ for Sections 87-13 and 84-33, 86-1, and 84-26. Below we first describe the distal deposits of the prodelta unit, which are dominated by beds that contain features consistent with previous interpretations of deposition by turbidity currents, including massive bedding, parallel lamination, and ripple stratification arranged in partial and full Bouma sequences (Table 1). Next, we describe the proximal and intermediate outcrop localities, which

Sandstone

Conglomerate

$\infty \infty$ Limestone nodules
FIG. 3.- Stratigraphic section showing the Minturn Formation as it occurs around McCoy, Colorado. Numbers 1-19 on the left are mappable units delineated by Chronic and Stevens (1958). The position of the turbidite unit of this study is also shown. 

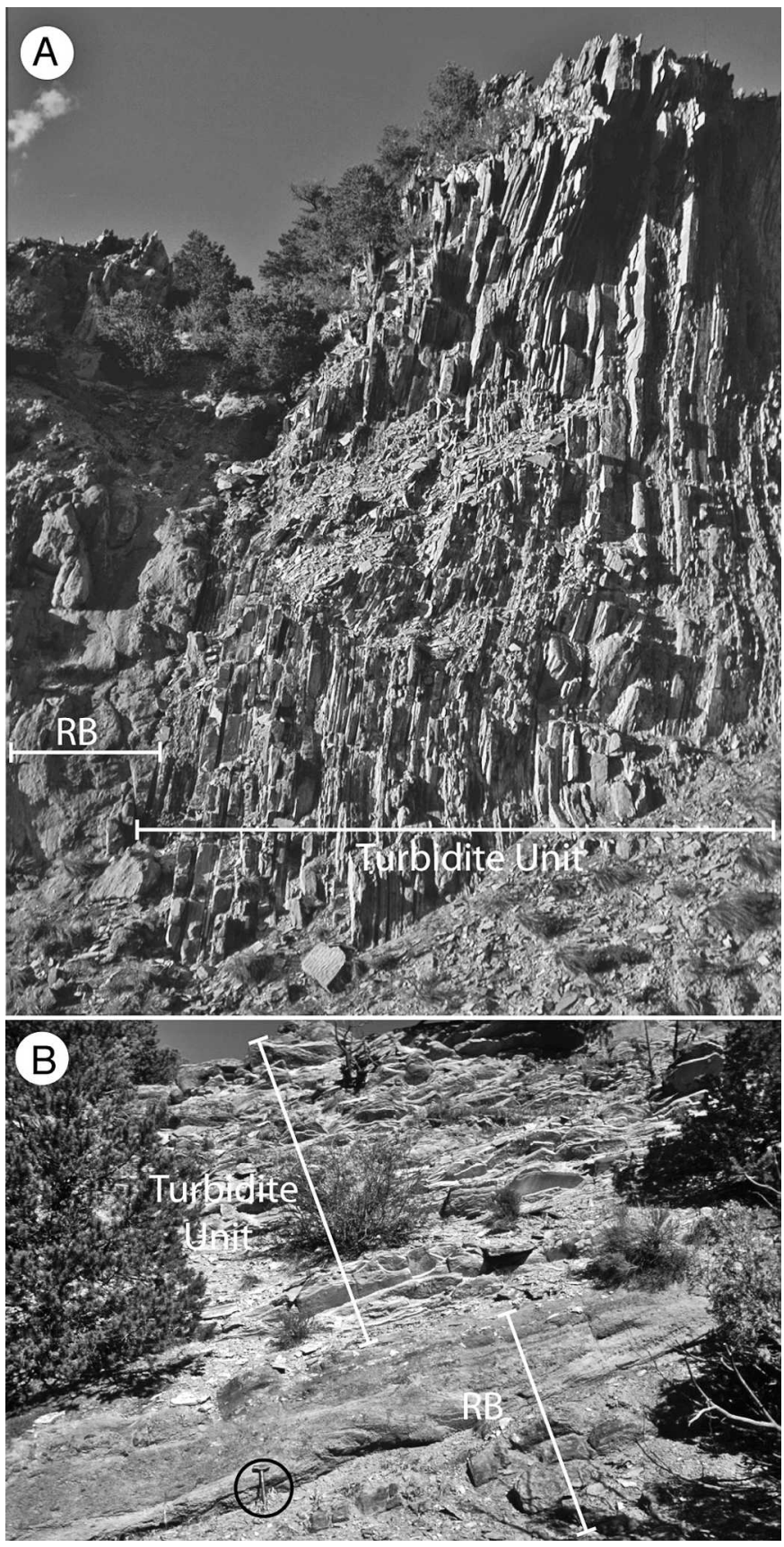

Fig. 4.-Prodelta unit. A) Exposure along road at 84-26 (Fig. 2); up direction is to left. RB = red bed unit above turbidites. B) Exposure on side of hill at site 861. Red beds below turbidite unit are in foreground. Sledge hammer is $37 \mathrm{~cm}$ long (circled). The red-bed units shown in this figure are typical fluvial deposits of the Minturn.

differ in that many beds contain evidence for deposition under combined oscillatory and unidirectional flow, including hummocky cross stratification (HCS) and quasi-planar lamination (Arnott 1993) (Table 1).

\section{Characteristics of Distal Deposits}

Distal outcrop locations 84-26, 85-4, and 04-1 contain fine-grained (almost exclusively siltstone to fine sandstone), thin to medium event beds (average $11 \mathrm{~cm}$ thick) and shale. Because of poor exposure, and to avoid redundancy, only the lower $6 \mathrm{~m}$ of 85-4 and 04-1 are presented (Fig. 5).
TABLe 1.- Sedimentological and stratigraphic data for the event beds of the Minturn Formation.

\begin{tabular}{lcccc}
\hline \hline & distal & intermediate & proximal & proximal \\
& $84-26$ & $86-1$ & $84-33$ & $87-13^{*}$ \\
\hline Section thickness $(\mathrm{m})$ & 18.8 & 19.8 & 35.3 & 12.4 \\
Percent sandstone & 35 & 30 & 33 & 32 \\
Number of event beds & 60 & 38 & 81 & 24 \\
Percent of beds > 15 cm thick & 19 & 16 & 35 & 39 \\
\% Partial or full Bouma sequences & 38 & 26 & 10 & 4 \\
\% HCS, quasi-planar beds & 8 & 34 & 32 & 21 \\
\hline
\end{tabular}

* only lower part of section was measured.

85-4 and 04-1 are not given because only lower $6 \mathrm{~m}$ of section was exposed All beds greater than $3 \mathrm{~cm}$ are documented.

The remainders of these sections are similar to section 84-26 (Fig. 6), which is the best-exposed distal outcrop, and is thus the focus of the following observations. The distal event beds have many characteristics typical of deposition from waning unidirectional flows (e.g., turbidity currents) such as normal grading, well-developed sole marks, and particular successions of stratification. Sedimentary structures include massive bedding, parallel lamination, and climbing-ripple cross stratification (Fig. 7). Thirty-eight percent of the beds in Section 84-26 contain sedimentary structures arranged in partial (Fig. 7A) or complete (Fig. 7B) Bouma sequences (Table 1). Some event beds also show prominent reverse-to-normal grading, and in many cases, sequences of sedimentary structures that indicate waxing and waning flow (i.e., ripple cross stratification overlain by parallel lamination and capped by ripple cross stratification). The beds also contain sole marks, such as casts of flutes, grooves, drag marks, and prod marks. The paleocurrent directions as indicated by ripples and sole marks indicate flow towards the southsouthwest (Fig. 8). It is these features that have led most previous workers to interpret the prodelta unit as a series of turbidites deposited in the absence of storm waves.

A variety of slump and mass-flow deposits occur within the basal $6 \mathrm{~m}$ of the turbidite unit at distal localities, particularly at locations 85-4 and 04-1 (Fig. 5). Evidence for mass flows includes thin $(3-8 \mathrm{~cm})$ lenticular beds of pebbly mudstone, which consist of dark shale with floating, subrounded, fine sand grains to pebbles of feldspar and quartz. The debris makes up 15 to $35 \%$ of the beds and contains pebbles up to $12 \mathrm{~mm} \times 8 \mathrm{~mm} \times 6 \mathrm{~mm}$. These pebbles occur in association with shale beds that include variably sized fragments of contorted sandstone. The fragments or "rafts" of sandstone occur at different positions within the bed, and are encased in a shale matrix. These remnants of partially deformed bedding range in size from $8 \mathrm{~cm} \times 10 \mathrm{~cm}$ to $20 \mathrm{~cm} \times 50 \mathrm{~cm}$ in cross section. In one case, at $3.96 \mathrm{~m}$ in Section 85-4, a 4-6 cm thick bed of shale with coarse sand to granule-sized grains is overlain by $46 \mathrm{~cm}$ of shale with sandstone rafts at both the base and top (Fig. 5). The rafts at the base are nearly tabular, only mildly distorted, and are oriented subhorizontally. The upper clasts are far more contorted and are at more random orientations. The matrix of the bed also contains abundant floating fine to medium muscovite sand grains.

Another notable raft-bearing shale bed occurs at $3.44 \mathrm{~m}$ of Section 04-1 and consists of $20 \mathrm{~cm}$ of contorted rafts of laminated sandstone in shale. This bed rests above an upward-coarsening succession that begins at the base of the unit and culminates in $80 \mathrm{~cm}$ of fine- to medium-grained sandstone. At the top of the sandstone is a 30 -cm-thick bed with ball-andpillow structures that is the thickest (by a factor of nearly two) noted in any of the sections of the turbidite unit. The top of the ball-and-pillow bed is littered with widely spaced, rounded granite clasts up to $5 \mathrm{~cm} \times 4 \mathrm{~cm} \times 2 \mathrm{~cm}$. It should be noted that a ball-and-pillow bed also occurs in proximal Section 87-13 (Fig. 9, discussed below) at almost 


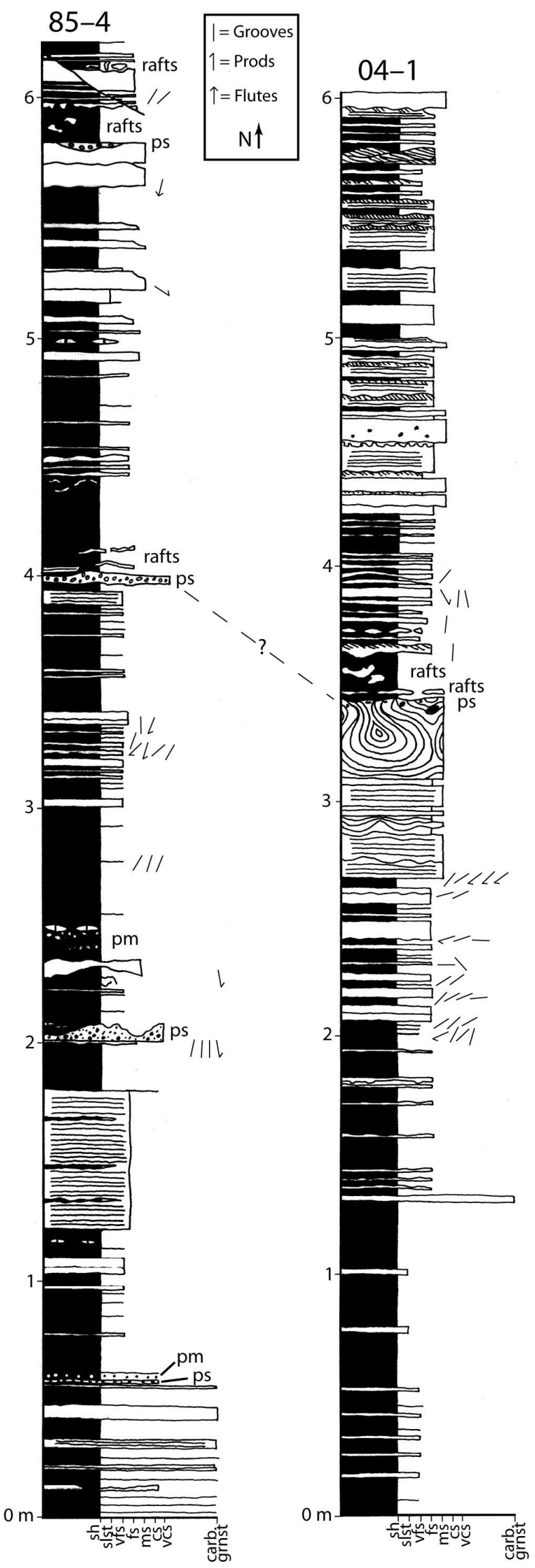

\section{Legend}

\begin{tabular}{|c|c|}
\hline & $\begin{array}{l}\text { Ball-and-Pillow } \\
\text { Features }\end{array}$ \\
\hline & $\begin{array}{l}\text { Climbing-Ripple } \\
\text { Lamination }\end{array}$ \\
\hline & $\begin{array}{l}\text { Quasi-Planar } \\
\text { Lamination }\end{array}$ \\
\hline & Parallel Lamination \\
\hline & $\begin{array}{l}\text { Hummocky Cross } \\
\text { Stratification }\end{array}$ \\
\hline & Sandstone \\
\hline & Shaly Siltstone \\
\hline & Shale \\
\hline & Cover \\
\hline
\end{tabular}

FIG. 5.-Continued.

the exact same stratigraphic position ( $3.06 \mathrm{~m}$ as opposed to $3.14 \mathrm{~m}$ in Section 04-1) and is the only ball-and-pillow bed in the lower $12 \mathrm{~m}$ of that section. Data from Section 04-1 indicate a shift from southwestern- to southeastern-directed paleocurrents below and above this raft-bearing bed (Figs. 5, 10). A similar shift of paleocurrents is noted in Section 85-4, and it takes place in the vicinity of an 18-cm-thick raft-bearing bed at $5.81 \mathrm{~m}$ (Figs. 5, 10). The bed rests directly on a 17-cm-thick amalgamated fine-grained to medium-grained sandstone bed that is capped with a lens of coarse (medium sand to granule) debris.

\section{Characteristics of Proximal and Intermediate Deposits}

While the proximal and intermediate outcrops contain some event beds similar to those in the distal settings, these outcrops differ in that they contain many more beds with features known to form under strong waves (Table 1). The most prominent feature is low-angle, curved lamination $\left(<20^{\circ}\right)$ with associated curved, low-angle erosion surfaces. The laminae form convex-upward hummocks and broad swales, and in many instances the erosion surfaces can be traced upward into conformable lamination of a swale. These features of the stratification clearly indicate that the lamination is hummocky cross stratification. The turbidite unit at proximal locality $84-33$ is $35.3 \mathrm{~m}$ thick (Fig. 11) and $32 \%$ of the sandstone beds contain small- to large-scale hummocky cross stratification (HCS), combined-flow ripples (e.g., Fig. 12B, D), or quasi-planar lamination (Table 1). Sandstone beds with large-scale HCS (spacings of

FIG. 5.- Stratigraphic sections 85-4 and 04-1. Paleocurrents from grooves, prods, and flutes are plotted next to the stratigraphic section using arrows (north is to top of page). PS = pebbly sandstone, $\mathrm{PM}=$ pebbly mudstone debrite. See Figure 2 for location. 

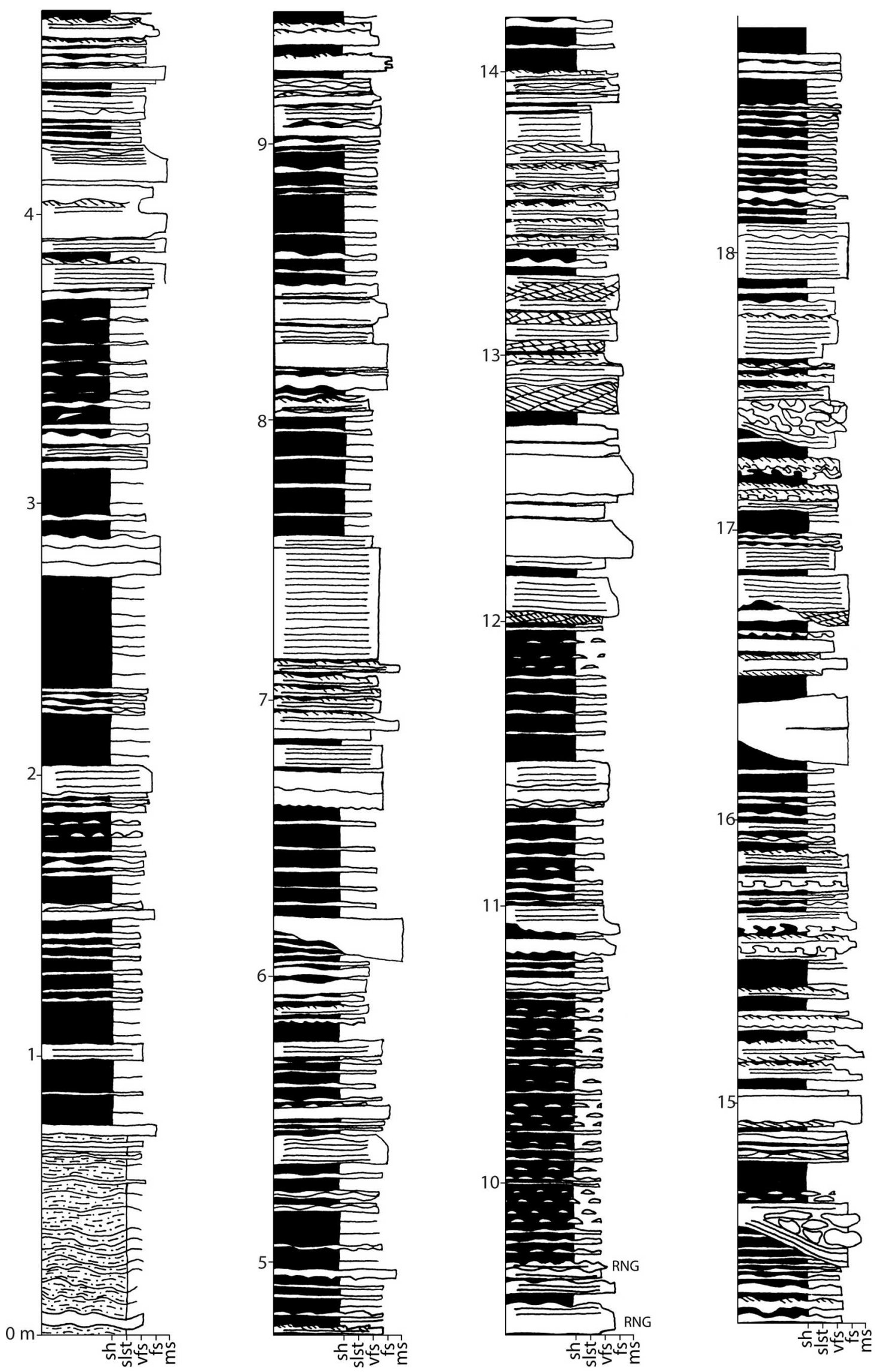

FIG. 6.- Stratigraphic section 84-26. RNG = reverse-to-normal grading. Location of section is shown in Figure 2. See key for Figure 5. 


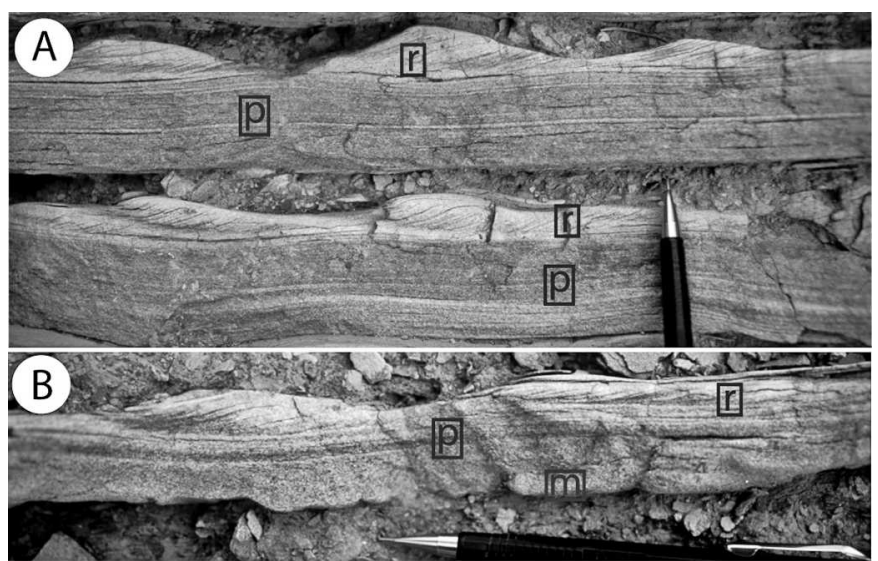

FIG. 7.- A) Two normally graded beds at location 84-26 with paralle lamination (p) and overlying ripples (r). Pencil for scale is $14 \mathrm{~cm}$ long and tip is $2 \mathrm{~cm}$ long. B) Normally graded bed at location 84-26 with classic Bouma sequence of massive $(\mathrm{m})$ to parallel-laminated to ripple-laminated divisions.

hummocks $\sim 1 \mathrm{~m}$ or more; Fig. $12 \mathrm{H}, \mathrm{I})$, parallel lamination, and quasiplanar lamination (e.g., Fig. 12F) are extremely abundant between 6 and $11 \mathrm{~m}$ of this section (Fig. 11). Proximal locality 87-13 also contains a large percentage of event beds with HCS and quasi-planar lamination (21\%: Table 1), although only the basal $12 \mathrm{~m}$ of the prodelta unit is well exposed (Fig. 9). The lower $1.97 \mathrm{~m}$ of this section is mostly shale, and includes a prominent shale marker bed at $1.43 \mathrm{~m}$. A particularly thick $(1.65 \mathrm{~m})$ sandstone unit is developed at $1.97 \mathrm{~m}$, which contains small-scale HCS (Fig. 12E) and combined-flow ripples. The intermediate Section 86-1 is $19.8 \mathrm{~m}$ thick and contains many of the same features prominent in the more proximal localities, as well as a number of beds typical of the distal localities (Table 1). The stratigraphic section for this locality is shown in Lamb et al. (2008) and for brevity is not presented here.

Amalgamated beds of sandstone reach up to $1.6 \mathrm{~m}$ thick in the proximal sections and consist of massive, parallel-laminated, quasi-planar and HCS divisions. The most common vertical stratification sequences of oscillatory-flow and combined-flow sedimentary structures are represented schematically in Figure 13. Large-scale HCS commonly occurs in thicker beds ( $>\sim 15 \mathrm{~cm}$; Table 1), and individual beds of HCS locally exceed $50 \mathrm{~cm}$ in thickness. The apparent wavelength of hummocks on vertical outcrop faces is generally $1 \mathrm{~m}$ or more (locally up to 2-3 m), and heights are in many cases up to a few tens of centimeters. Many sandstone beds, particularly at Section 86-1, consist of parallel laminated and HCS divisions capped by divisions of combined-flow ripple lamination up to $12 \mathrm{~cm}$ thick. Preserved ripple form sets and ripple cross stratification have unusual geometries relative to either typical current or wave ripples, namely rounded crests, nearly symmetrical shape, and unimodally dipping, convex-up or sigmoidal foresets (Fig. 12B, C, D). All examples of ripple stratification show transport towards the southern quadrants. Examples of asymmetrical HCS have steeper lamination or preserved bedform sides on their southern limbs (e.g., Fig. 12G), and thus also record bedform migration towards the south. Quasi-planar lamination is common and locally contains minor combined-flow ripple lamination. Such beds reach up to $60 \mathrm{~cm}$ in thickness. Planar lamination, quasiplanar lamination, and hummocky cross stratification are generally found within nongraded very fine to fine sandstone beds.

Sole marks are less abundant than in distal outcrops, in part because bedding soles are not as well exposed. These include groove marks, drag marks, chevron marks, prod marks, gutter casts, and less commonly, flute marks. As demonstrated by Houck (1991, 1993), sole marks display paleocurrent orientations generally towards the south: more southwest at localities 87-13 and 84-33, and generally SSE at locality 86-1 (Fig. 8).
Some sandstone beds have considerable erosional relief along their bases (particularly in Section 84-33, Fig. 11). One bed at $18 \mathrm{~m}$ in Section 84-33 has $54 \mathrm{~cm}$ of basal relief overlain by $84 \mathrm{~cm}$ of massive, medium-grained sandstone, which is then capped by $20 \mathrm{~cm}$ of HCS fine sandstone and finally a few centimeters of combined-flow-ripple-laminated, very fine sandstone (Fig. 11).

\section{INTERPRETATION}

Stratigraphic and sedimentological data from the Minturn Formation event-bed unit indicate deposition of prodeltaic facies within a thick succession of fan-delta deposits. Presumably the unit was deposited during the Desmoinesian-age Inola transgression in the US mid-continent (Houck 1993, 1997). The pebbly mudstone and raft-bearing beds in the lower $6 \mathrm{~m}$ of distal sections are clear evidence of deposition from mass flows. The largest clasts of the pebbly mudstone beds are nearly an order of magnitude larger than the largest grains that occur within the other event beds. Coarse sand, granules, and pebbles are common in the underlying and overlying fan-delta and fluvial deposits of the Minturn Formation. The occurrence of these pebbly mudstone beds solely within the basal $6 \mathrm{~m}$ of the turbidite unit indicates that during initial transgression, above the underlying unconformity, fluvial and shoreline environments were relatively proximal. Transgressive reworking of the underlying unconformity surface may have mobilized some coarse material, which was then transported downslope as mass flows. The fabric of the pebbly mudstone beds, with floating coarse clasts within mudstone, reflects debris-flow deposition (e.g., Hampton 1972). Similar thin pebbly mudstone debrite beds have been described from muddy shallow-marine deltaic deposits (e.g., Myrow and Hiscott 1991). The pebble debris in these beds was mobilized from proximal coarse-grained facies, most likely delta-front or distributary-mouth-bar deposits. The raft-bearing beds are also evidence of deposition from mass flows. In this case, the range of fabrics, from partially preserved bedding to contorted and random clasts, reflects a spectrum of stages of evolution from deformation of intact bedding, to slumping, to mass flow with dismembered bedding as clasts (cf. Myrow and Hiscott 1991).

Previous authors (Houck 1993; Kairo et al. 1993; Soulliere et al. 1984; Lindsey et al. 1986; Schenk 1986, 1989; Hoy and Ridgway 2002, 2003) interpreted these and other sandstone event beds in the Minturn Formation and Eagle Valley Evaporite as turbidites, on the basis of the abundance of such features as unidirectional sole marks, current ripples, normally graded bedding, and Bouma sequences. We concur that the many of the beds in the study area show evidence for deposition under decelerating unidirectional currents consistent with turbidity currents. This is especially true for distal sections, which contain a high percentage of partial and full Bouma sequences (Table 1). These currents contained abundant woody debris that resulted in a variety of tool marks, which along with ripple paleocurrent data suggest south oriented transport of sediment under turbidity-current flow. This flow direction is consistent with regional paleogeographic reconstructions for downslope-oriented flow (Houck 1993, 1997) (Fig. 2).

Unlike previous work, our observations indicate that deposition in the study area took place in a range of conditions within the prodelta. Limestone beds within the lower part of the prodelta unit at several localities along the outcrop belt east of Bond and Copper Spur (Fig. 2) contain typical Pennsylvanian shallow-water open-marine fauna (brachiopods, bryozoans, echinoderms). Wave-generated stratification, noted by both Houck (1993) and Kairo et al. (1993), includes HCS and quasiplanar lamination, and its presence in more proximal strata indicates that they were deposited in relatively shallow water under the influence of storm-generated waves. The presence of hummocky cross stratification (Hamblin and Walker 1979; Kreisa 1981; Dott and Bourgeois 1982) and quasi-planar lamination (Arnott 1993) is clear evidence of storm 


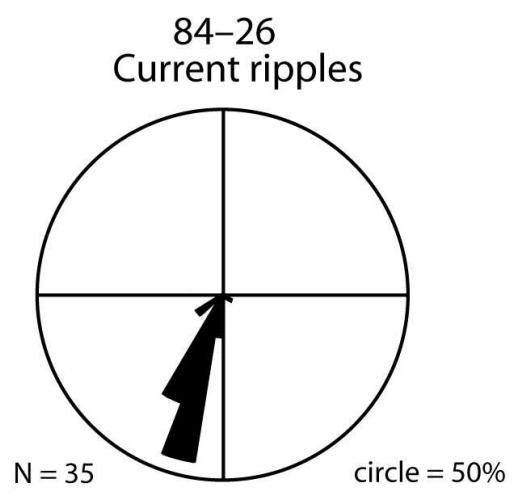

86-1 Current ripples

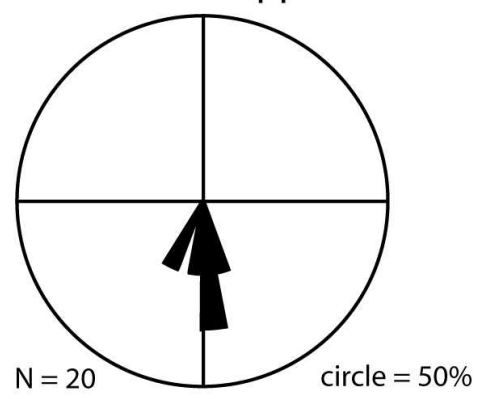

$84-33$

Tool marks

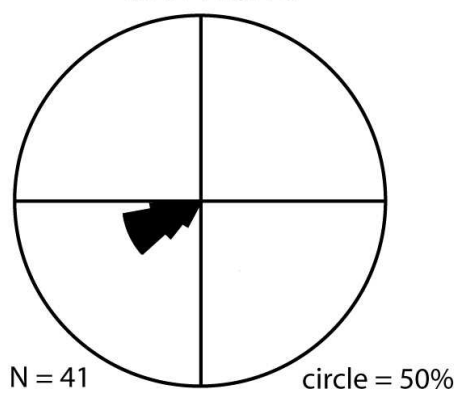

$84-26$ Tool marks

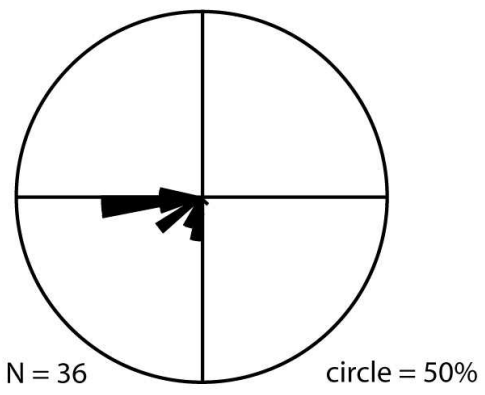

86-1 Tool marks

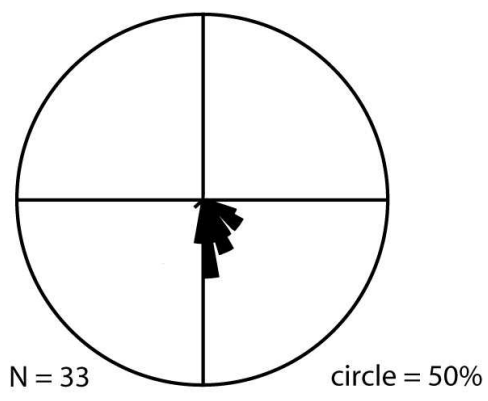

$87-13$ Tool marks

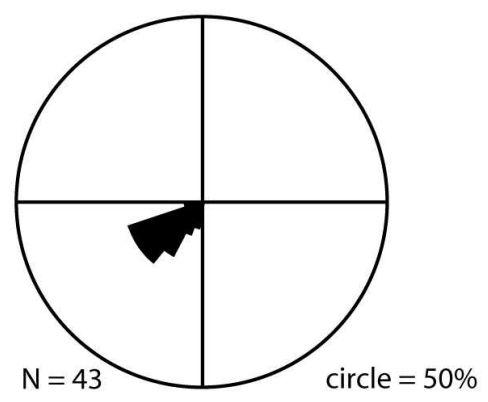

FIG. 8.- Rose diagrams for various sedimentary structures from field sites shown in Figure 2 (from Houck 1993). deposition. HCS is well documented in both experimental work and field studies to result from long-period complex oscillatory flow or wavedominated combined flow (Harms et al. 1975; Duke 1990; Duke et al. 1991; Southard et al. 1990; Arnott and Southard 1990; Dumas et al. 2005). Strong combined flows were likely responsible for the asymmetric HCS (Arnott and Southard 1990; Dumas et al. 2005) that is common in the proximal outcrops. The geometry of ripple stratification (i.e., rounded crests and convex-up or sigmoidal foresets) in some beds also reflects deposition under weaker combined flows, with both unidirectional and oscillatory components (Yokokawa 1995; Yokokawa et al. 1995).

Our findings are generally consistent with early facies models for storm-dominated shelves, which showed proximal oscillatory-flowdominated facies grading into thin distal beds with turbidite features (Hamblin and Walker 1979; Wright and Walker 1982; Dott and Bourgeois 1982). However, the upslope deposits of the Minturn show evidence for combined flows (e.g., asymmetric HCS and rounded ripples with sigmoidal forests), whereas more distal outcrops show evidence for strong unidirectional flows (e.g., flutes and current ripples). Of note is an absence of purely oscillatory-flow structures that are extremely abundant in most storm-influenced shelves, namely isotropic HCS and 2D (straightcrested) wave ripples. This suggests that in all cases large waves occurred in conjunction with strong unidirectional currents during deposition of these beds.

It is not yet clear how the proximal combined-flow-dominated deposits relate to the more distal current-dominated deposits. While individual beds cannot be traced due to cover, the distance between intermediate section 86-1, with abundant HCS, and the distal section 84-26, which shows little evidence for deposition under oscillatory or combined flows, is only $0.5 \mathrm{~km}$ (Fig. 2). In addition, proximal, intermediate, and distal deposits contain nearly the same percentage of sandstone (Table 1), and exhibit similar paleocurrent directions (Fig. 8). Most importantly, all show evidence for deposition from bottom-hugging flows that were laden with plant debris. Two possible mechanisms could explain both proximal and distal beds being formed during the same events. First, large storms could trigger dense hyperpycnal river plumes (e.g., Mulder et al. 2003). If the turbidity currents generated from these plumes traveled through a 

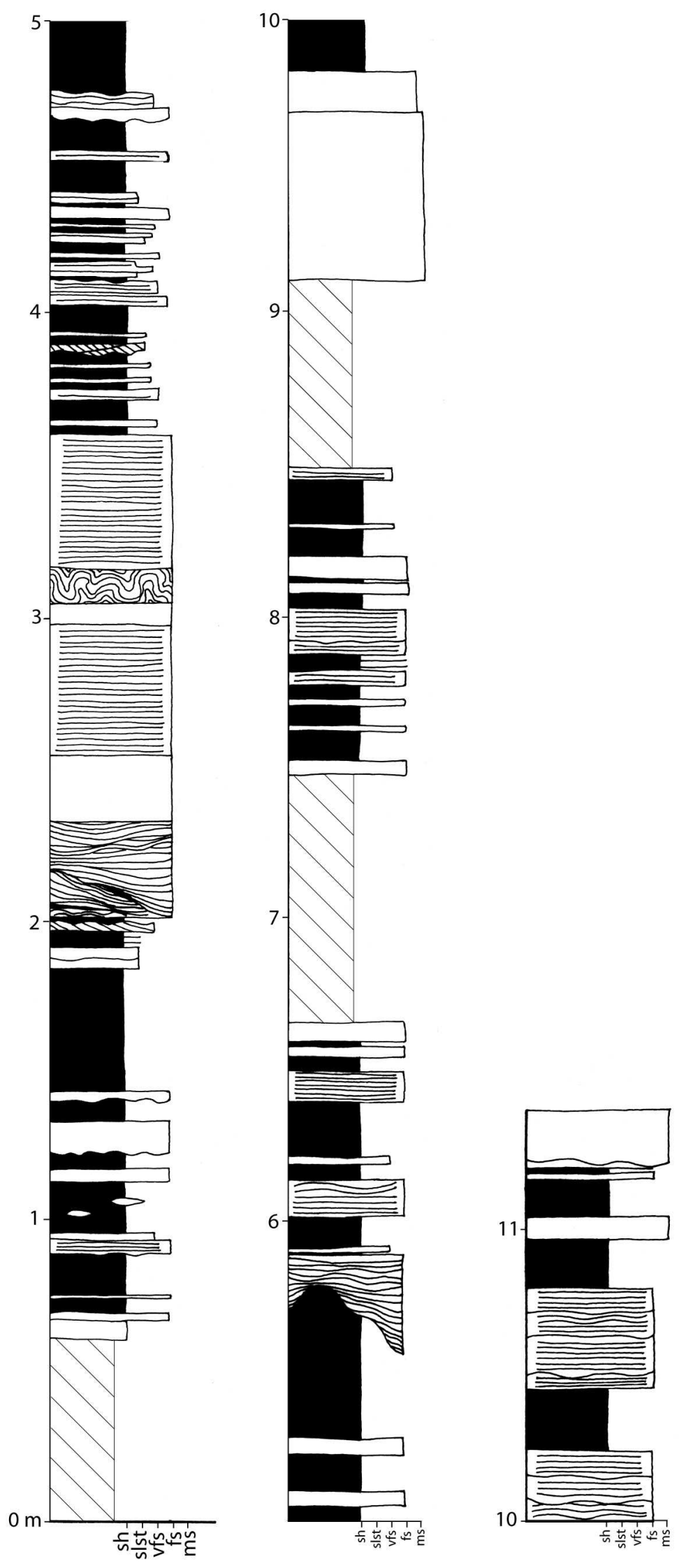

FIG. 9.- Stratigraphic Section 87-13. Location of section is shown in Figure 2. See key for Figure 5. 


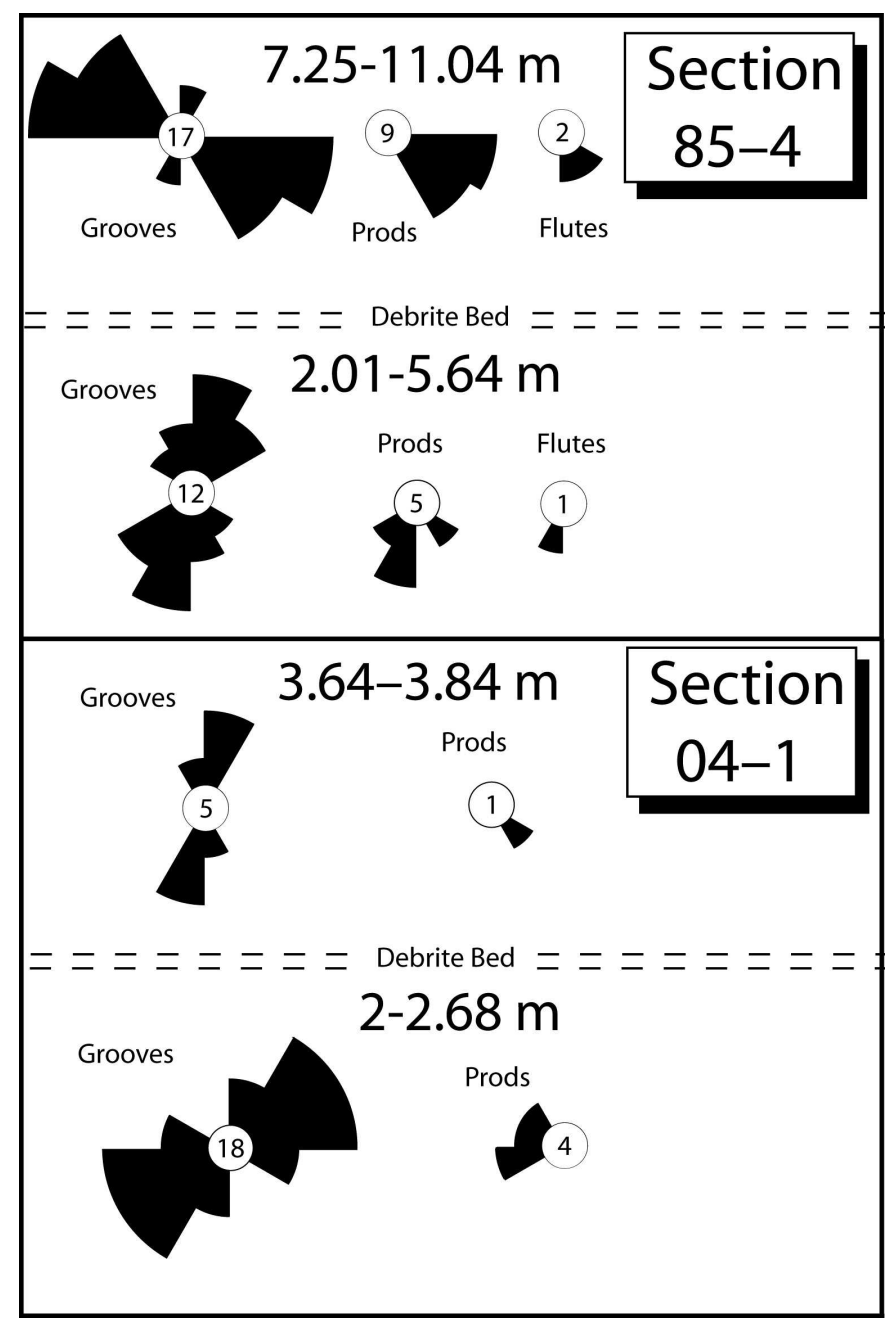

FIG. 10.- Equal-area paleocurrent rose diagrams for data collected from Sections 85-4 and 04-1 (number of readings in center of rose diagram). These are grouped for those taken below and above a regional debrite marker bed, which exists stratigraphically at $5.81 \mathrm{~m}$ in Section $85-4$, and at $3.14 \mathrm{~m}$ at Section $04-1$.

nearshore environment influenced by oscillatory flow (due to storm waves), then their deposits would reflect deposition under the combined effects of waves and currents (Fig. 14). Second, turbidity currents might have been sourced from nearshore slumps of the delta face, possibly triggered by high pore-fluid pressures associated with cyclic wave loading. Distinguishing between these turbidity current initiation mechanisms is beyond the scope of this paper, but is addressed in Lamb et al. (2008).

Whatever the mechanisms for initiating the turbidity currents, it is clear that these flows must have traveled through a nearshore environment that was strongly affected by large storm waves. In the following sections we explore the paleogeographic and paleoclimatic implications of this finding.

\section{PALEOGEOGRAPHY AND DEPOSITIONAL HISTORY}

The turbidite unit in this study is underlain by coarse conglomerate, and the contact represents an Atokan-Desmoinesian boundary unconformity (Houck 1993). The fact that there is no well-sorted sandstone-dominated facies directly above this unconformity indicates that the ensuing transgression was too rapid to have accumulated shoreline deposits. The shale-rich interval with little sandstone at the base of the turbidite unit reflects alluviation of the river systems during landward migration of the shoreline and rise of base level. Thus, at this time, sand was largely trapped upstream in the alluvial system and possibly, in part, in the landwardshifting shoreline. The presence of scattered pebbly beds and various slump deposits, including raft-bearing mudstone debrites, suggests that unstable muddy deltaic shoreline sources existed during initial transgression (e.g., Myrow and Hiscott 1991). The change in paleocurrent orientations at Section 04-1 from southwestern to southeastern orientations at this same level might be a result of reorganization of the sediment-dispersal system that carried turbidity currents (e.g., avulsion of submarine channels and prodelta lobes). Numerical models of fan-delta deposition emphasize the importance of avulsion on the morphodynamics of these depositional systems (Sun et al. 2002), and these prodelta deposits might record such processes. Further transgression likely resulted in the establishment of lower-prodelta environments characterized by more stable slopes on which the turbidites were deposited.

The unconformity that underlies the turbidite unit shows evidence for topographic relief, and the turbidites were thought by Houck (1993) to have been deposited in two 1-2 km long, south- and southwest-oriented incised valleys located in the eastern and western parts of the study area. The first is along the trend of the outcrops described in this study, and the second is along a ridge that extends south from Copper Spur $\sim 1 \mathrm{~km}$ to the east (Fig. 2). The precise scale and geometry are difficult to constrain because of incomplete outcrop exposure. Stratigraphic data presented by Houck (1997, her fig. 10) indicate that there could be as much as 51-64 m of relief along this unconformity, although we have reanalyzed the stratigraphic data using an underlying limestone as a datum (Houck's Unit $3 \mathrm{~b}$ ), and it suggests that the relief is $\sim 20 \mathrm{~m}$. Even at this lower value, the valley relief was probably sufficient to influence flow paths during deposition of the prodelta unit.

Several lines of evidence suggest, however, that both the incised valleys and the interfluve regions were substantially flooded at this time. Estimates of the magnitude of fourth order sea-level changes during the Pennsylvanian include: 30-50 m (Wilson 1967), $100 \mathrm{~m}$ (Heckel 1986), and 50-150 m (Ross and Ross 1987), and these are of large enough magnitude to drown both the valleys and interfluves along the underlying unconformity. In addition, compared to nearly all other stratigraphic levels within the $\sim 500$-m-thick Minturn Formation, the shale-rich turbidite unit cannot be traced landward to shoreline and fluvial facies; it extends far into proximal regions where outcrop is lost due to erosion. This is also the case for the marine limestone beds, which also formed extensive units during transgression. The greater part of the Minturn deposits exhibit extraordinary lateral lithofacies transitions from a variety of delta-front and marginal marine fan-delta facies through more proximal fluvial and alluvial-fan deposits over short distances. Such lithofacies exist throughout the entire thickness of the formation and record frequent lateral and shore-perpendicular migration of environments during relative sea-level changes. Although the most proximal deposits of the turbidite unit contain some thick $(1.65 \mathrm{~m})$ amalgamated sandstone beds, particularly near the base, the unit is shale-rich throughout the field area and clearly was deposited well beyond the shoreline. Thus, at this time the shoreline migrated landward and well outside of the field area, as it was during deposition of highstand limestone beds and one other turbidite unit in the Minturn Formation (Houck 1997). The turbidite unit therefore records a particularly strong transgressive event, most likely the Inola mid-continental transgression of Ross and Ross (1987) (Houck 1997).

Perhaps the most significant evidence for substantial flooding of both incised valleys and interfluves is the presence of large-scale HCS within the turbidite unit. The formation of HCS requires large waves (Southard et al. 1990), and the scale of the HCS, which has wavelengths up to nearly $3 \mathrm{~m}$ and amplitudes of tens of centimeters, is on a par with those developed in ancient shelf deposits in areas of ocean-scale fetch (Walker 

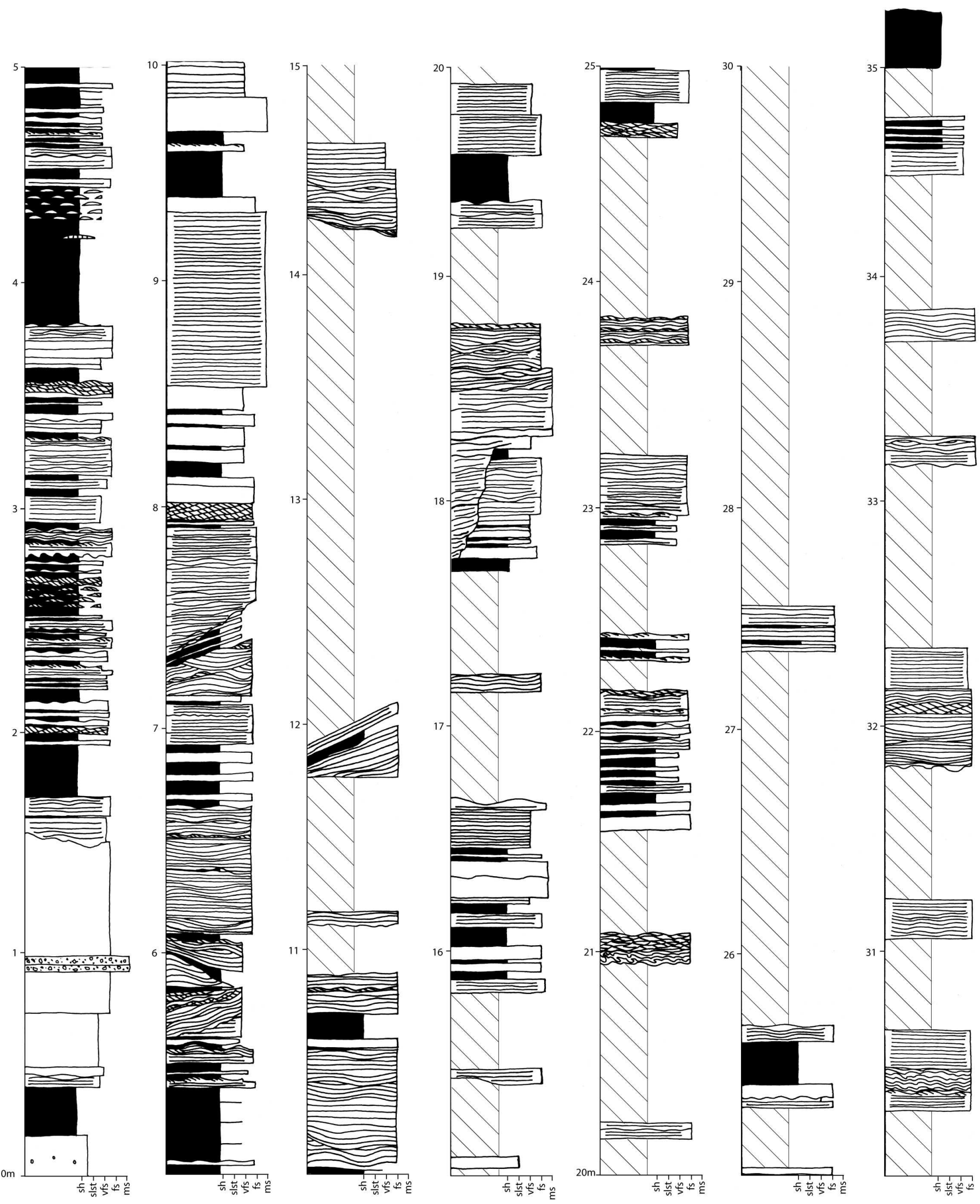

FIG. 11.-Stratigraphic Section for Section 84-33. Location of section is shown in Figure 2. See key for Figure 5. 

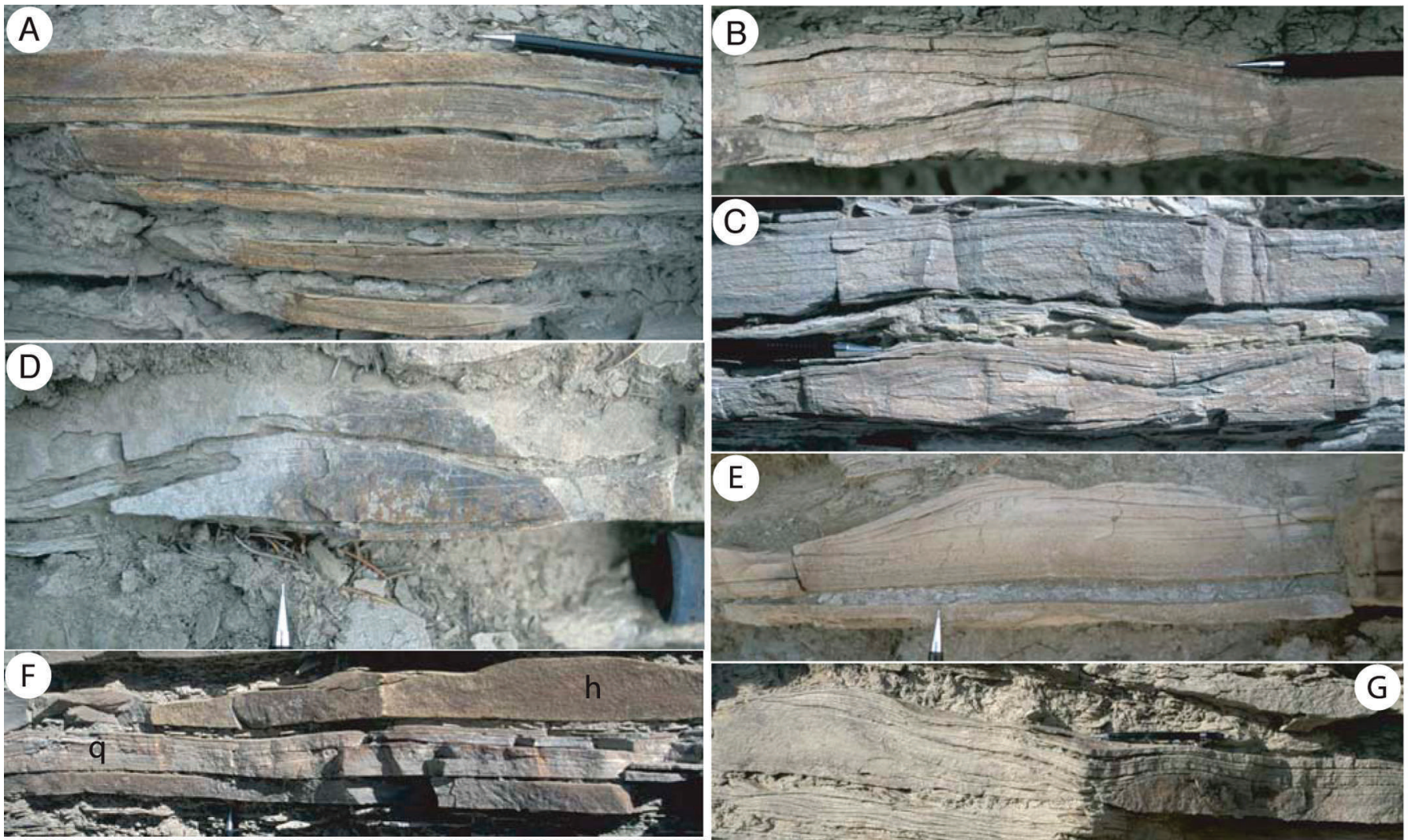

E
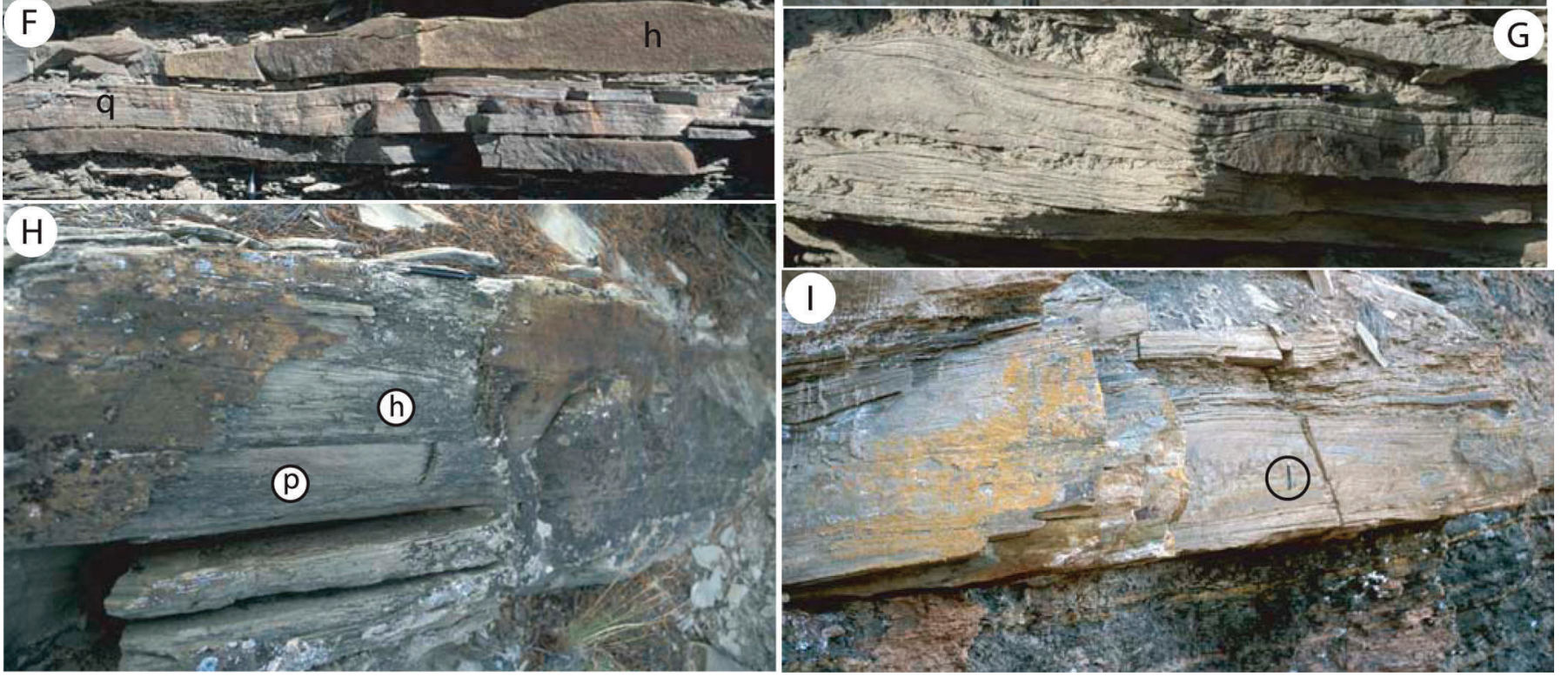

FIG. 12.-A) Small-scale HCS from 6.3 to $6.8 \mathrm{~m}$ in Section 86-1. B) Combined-flow ripple lamination from $5.61 \mathrm{~m}$ of section 84-33. C) Lower bed with combined-flow ripple lamination and draping lamination and upper bed with parallel lamination from $14.85 \mathrm{~m}$ of Section 84-26. D) Combined-flow ripple lamination from $3.29 \mathrm{~m}$ of section 84-33. Note nearly symmetrical cross section, rounded crest, and convex-up foresets. E) Parallel lamination and well-preserved hummocky bedform from Section 84-33. F) Quasi-planar laminated (q) and HCS (h) beds from $3.1 \mathrm{~m}$ of section 84-26. G) Three-dimensional view of small asymmetric hummocky bedform from $2.01 \mathrm{~m}$ at Section 87-13. Ripple-scale bedform at top of hummock in upper left shows migration to south reflecting migration under combined flow. $\mathbf{H}$ ) Bed at $8.86 \mathrm{~m}$ of Section 86 1 with parallel lamination (p) and HCS (h). I) Thick, large-scale HCS bed from a proximal section $3.5 \mathrm{~km}$ east of McCoy, CO. Pencil for scale is circled. Pencil in photos is $14 \mathrm{~cm}$ long and tip is $2 \mathrm{~cm}$ long.

1984). If the interfluves were not flooded, or barely flooded, it would not have been possible to produce large-scale wave motions within these confined spaces, for two reasons. First, the topography would have damped any large waves entering such a region. Second, the fetch within the purported valleys, whose widths would have been less than $2 \mathrm{~km}$ (Houck 1993), would have been too small to allow the production of waves large enough to produce HCS of this scale, unless the wave approach was fortuitously directly up-valley.

Recent experimental (Dumas et al. 2005) and modern oceanographic (Yang et al. 2006) observations have shown that the wavelength of large wave-dominated combined-flow bedforms $(\lambda>100 \mathrm{~cm})$ scale directly with the wave orbital diameter $\left(d_{o}\right)$. For the Minturn prodelta unit, a conservative upper bound for HCS wavelengths is $2 \mathrm{~m}$, which yields a corresponding wave orbital diameter of $3.1 \mathrm{~m}$ following the relationship $\lambda=0.52 d_{o}+38.5$ proposed by Dumas et al. (2005), where values are in centimeters. The maximum orbital velocity for shallow or intermediate water depths is defined as (e.g., Komar 1998)

$$
U_{w}=\pi d_{o} / T
$$




\section{No Grading}

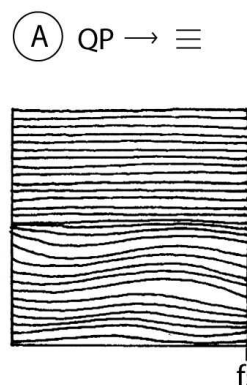

(B) $\cong \rightarrow Q P$

(C) $\mathrm{HCS} \rightarrow \pi \rightarrow Q P$
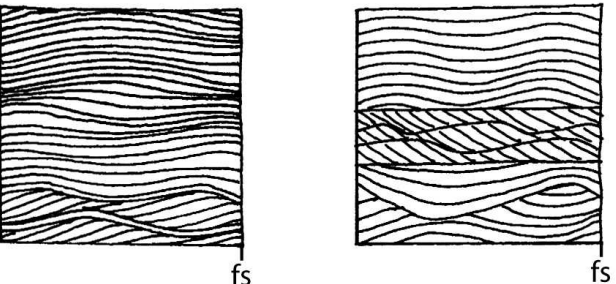

(D) $\equiv \rightarrow H C S / Q P$

(E) $Q P \rightarrow \ll$
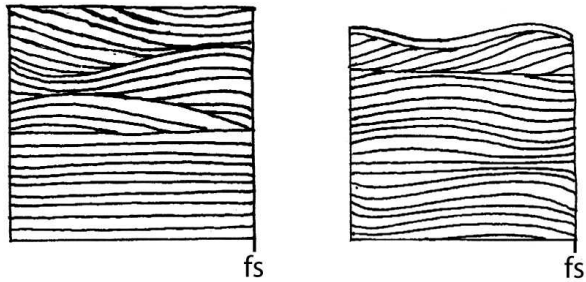

\section{LEGEND}

HCS : Hummocky cross stratification

QP : Quasi-planar lamination

$\equiv$ : Parallel lamination

: Combined-flow ripples

$\because::$ : massive s.s

\section{Normal Grading}

F $\equiv \rightarrow Q P$

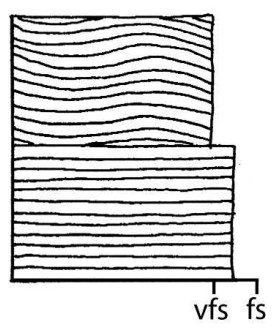

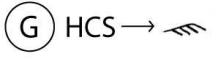

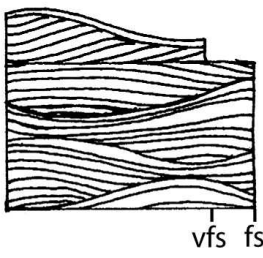

(H) $\because \because: \rightarrow \equiv \rightarrow$ $\mathrm{HCS} \rightarrow \pi$

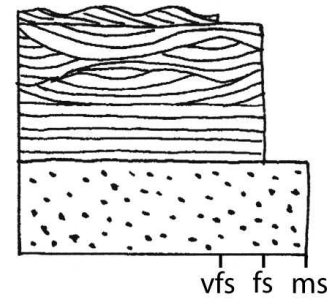

FIG. 13.-Common vertical stratification sequences observed with structures indicative of oscillation-dominated flow, such as hummocky cross stratification and quasi-parallel lamination. These include beds with no grading $(\mathbf{A}-\mathbf{E})$ and those with normal grading $(\mathbf{F}-\mathbf{H})$. The vertical stratification sequences illustrated exist within beds that range from a few centimeters to several decimeters in thickness. where $T$ is the wave period. The wave orbital velocity must not have exceeded approximately $1 \mathrm{~m} / \mathrm{s}$ during deposition of HCS according to the bedform stability diagram of Dumas et al. (2005). Therefore, by setting $U_{w}=1 \mathrm{~m} / \mathrm{s}$ and $d_{o}=3.1 \mathrm{~m}$, a minimum wave period of $9.7 \mathrm{~s}$ can be calculated from Equation 1.

Such a wave period and orbital diameter yield an infinite combination of possible water depths $h$ and wave heights $H$ according to Airy wave theory for intermediate depths:

$$
\begin{gathered}
H=d_{o} \sinh \left(\frac{2 \pi h}{L}\right) \\
L=\frac{g T^{2}}{2 \pi} \sqrt{\tanh \left(\frac{2 \pi h}{L}\right)}
\end{gathered}
$$

where $L$ is the wavelength of the wind-generated waves (e.g., Komar 1998), and $g$ is the acceleration due to gravity. The shaded region of Figure $15 \mathrm{~A}$ shows the possible combinations of wave heights and water depths for wave periods greater than or equal to our minimum estimate of $T=9.7 \mathrm{~s}$. Many of these combinations (e.g., $H=4 \mathrm{~m}, h=20 \mathrm{~m}$; $H=8 \mathrm{~m}, h=37 \mathrm{~m}$ ) seem reasonable for an open continental-shelf environment during large storms. Increasing the wave period yields larger water depths for a given wave height (Fig. 15A).

The fetch $F$ over which the wind blows with velocity $W$ needed to produce a given wave period can be estimated from the JONSWAP model for wind-generated waves (Hasselmann et al. 1976)

$$
\frac{W}{g T}=3.5\left(\frac{g F}{W^{2}}\right)^{-0.33}
$$

Figure 15B shows a range of possible combinations of fetch and wind velocity for a wave period greater than or equal to 9.7 seconds. We calculated a minimum fetch of $75 \mathrm{~km}$ by evaluating Equation 4 for our minimum estimate of wave period of $9.7 \mathrm{~s}$ and assuming a wind velocity of $W=50 \mathrm{~m} / \mathrm{s}$ (Fig. 15B), which should serve as a reasonable upper limit corresponding to hurricane-like conditions. The JONSWAP model was formulated for deep-water waves, which is consistent with calculating 


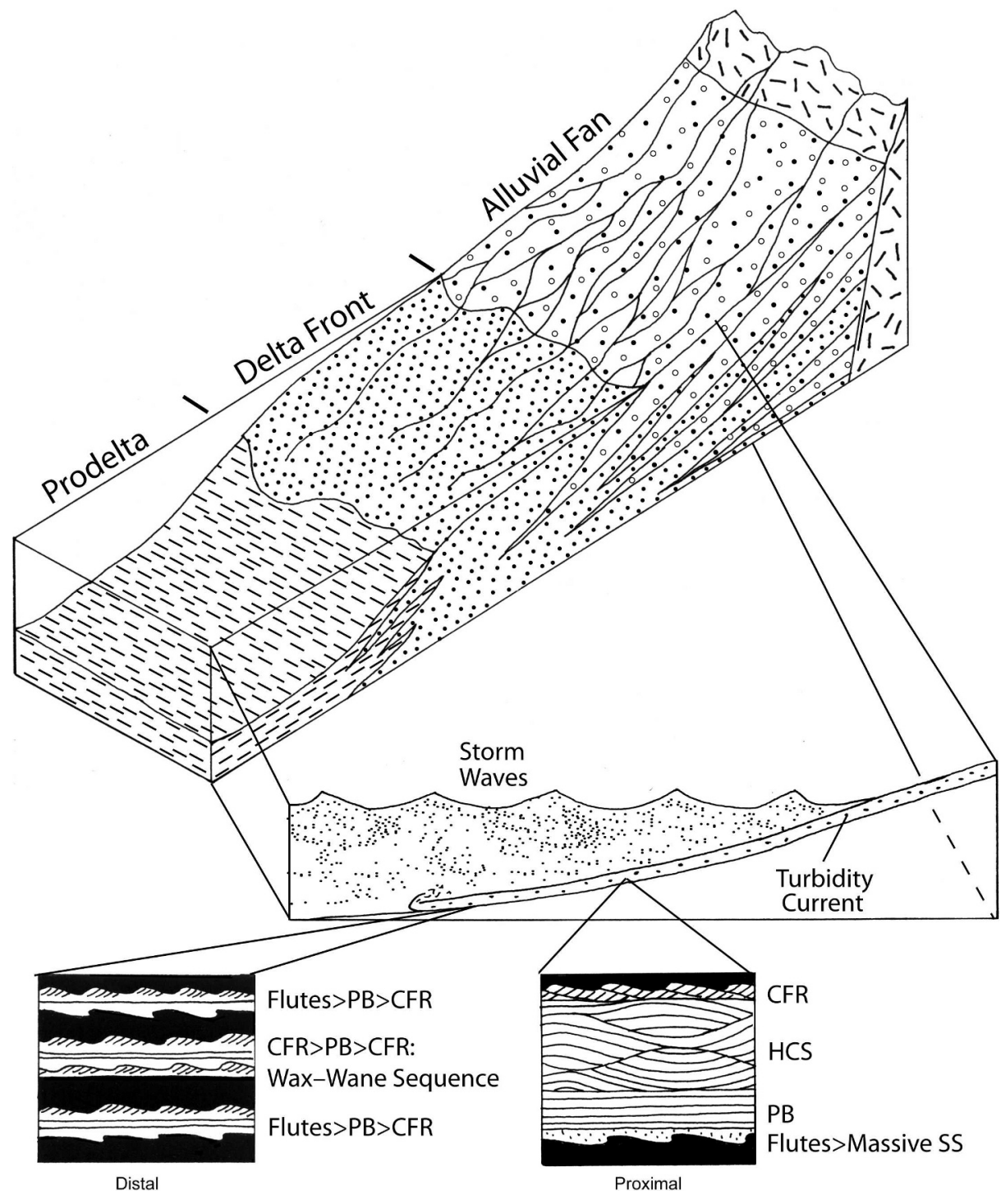

FIG. 14.-Cross-sectional reconstruction of depositional setting for wave-modified turbidites. Representative event beds are shown with flow from right to left. $\mathrm{PB}=$ upper plane bed lamination, $\mathrm{CFR}=$ combined-flow ripple lamination, HCS = hummocky cross-stratification, SS $=$ sandstone.
$F$ as a minimum since bottom friction would act to slow wave growth in the intermediate water depths considered here (Graber and Madsen 1988). These calculations indicate that, even under extremely windy conditions, the fetch must have been greater than $75 \mathrm{~km}$ to produce the observed HCS.

\section{PALEOCLIMATOLOGY}

Both the estimate of fetch that existed during deposition of the prodelta unit and the reconstructed paleogeography place constraint on the origin and movement of storm tracks in the Pennsylvanian Central Colorado Basin (CCB). The basin was situated at about $10^{\circ}$ North latitude at this time (North America was rotated counterclockwise relative to its presentday orientation) (Fig. 16; Johnson et al. 1992). In the following discussion, all azimuthal coordinates and directions are in reference to the paleogeographic reconstruction shown in Figure 16. The CCB was situated in the wind and rain shadow of the ancestral Front Range relative to dry easterly trade winds that would have blown across Pangea. However, eolian bedform migration directions (Peterson 1998) and oxygen isotope data in paleosols suggest that dominant equatorial winds might have been reversed (i.e., westerly) (Tabor and Montañez 2002). This might have resulted from deflection of zonal flow (trade winds) to mid-latitudes due to uplift of the Allegheny and Ouachita Mountains, which would in part explain widespread late Pennsylvanian eolian deposits during lowstands, including those that are contemporaneous with parts of the Minturn Formation (Weber, Tensleep, and Casper formations; Blakey et al. 1988), and their paleocurrents. A more radical interpretation is that the present-day southwest U.S. was in fact in the southern hemisphere and thus records a very different wind regime (Rowe et al. 2007), a scenario that would, however, require dismissal of a large database of paleomagnetic data.

Storms that affected the CCB, which were responsible for large waves that produced HCS and flooding that potentially led to hyperpycnal turbidity currents, could have tracked from two possible areas, as shown in the sea-level-highstand reconstruction of Figure 16. First, storms may have tracked from the south through a small opening within the Ouachita-Marathon suture zone and into the straits of the CCB. Such storm directions would be at a very high angle to equatorial zonal flow, although if the intertropical convergence zone (ITCZ) moved above $10^{\circ}$ North latitude during summer months, such a direction would be possible (Soreghan et al. 2002a). In any case, these storms would not likely be cyclonic because, at the low paleolatitudes $\left(<10^{\circ}\right)$ of the CCB at the time, cyclonic storms would be rare and relatively weak due to small Coriolis forces (Emanuel 2003). 

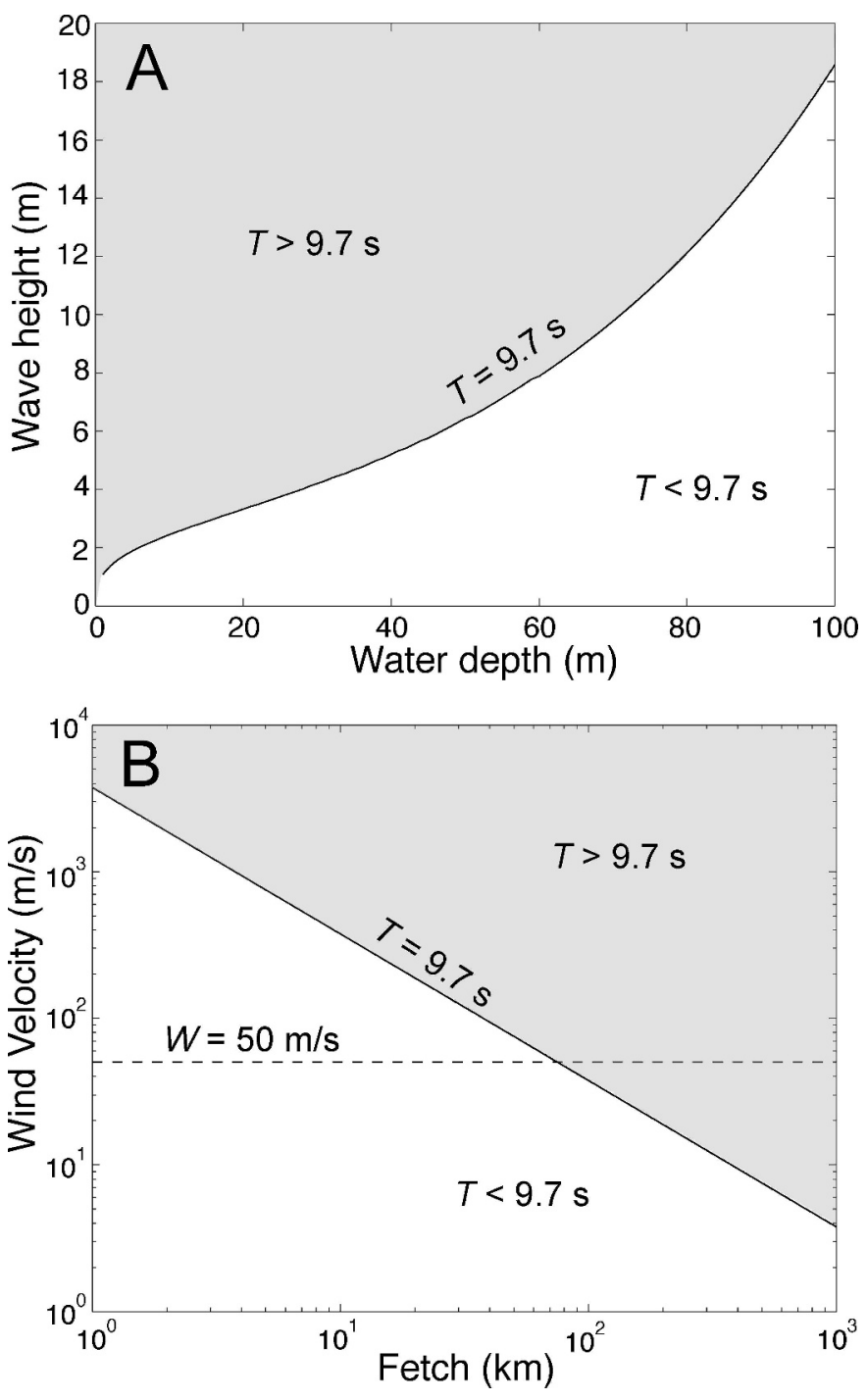

FIG. 15.-A) Calculated wave heights and water depths using Equations 2 and 3 necessary to produce waves of a given period for an orbital diameter of $3.1 \mathrm{~m}$. B) Calculated fetch and wind velocity necessary to produce waves with a given period using Equation 4. The dashed line is our estimate of a maximum wind velocity of $W=50 \mathrm{~m} / \mathrm{s}$. In both plots the shaded region represents the parameter space for a wave period equal to or greater than our minimum estimate of $T=9.7 \mathrm{~s}$.

A more likely scenario is that storms formed to the northwest, east of the Antler Mountain region, and moved across the Cordilleran seaway to the CCB. The Cordilleran seaway may have been as much as $600 \mathrm{~km}$ wide at the time of maximum transgression associated with the prodelta unit, and such a fetch would have been large enough to generate powerful waves. The northern end of the CCB would have been open to receive large storm-generated swell from the seaway, and storms might have passed over the Uncompaghre Mountains, depending on the mountain height. Once again, cyclonic storms would have been unlikely, in this case because modern tropical cyclonic storms tend to track westward and then north in the northern hemisphere as they veer under the influence of the Coriolis force, not southeast (Emanuel 2003). However, this scenario is consistent with climate reconstructions for the late Pennsylvanian that suggest monsoonal circulation during summer months with storm tracks and winds from the northwest (Parrish and Peterson 1988; Parish 1993; Patzkowski et al. 1991). In this case, such climate patterns would represent the southwestern sector of a large counterclockwise circulation pattern located around a high-pressure zone over the low mid-latitude part of northern Pangea (present-day south-central U.S.) (Patzkowski et al. 1991). This monsoonal circulation pattern, which is interpreted to have increased in importance during the Pennsylvanian-Permian transition (Parrish 1993; Soreghan et al. 2002b), would have brought moisture-laden air into the $\mathrm{CCB}$, consistent with major flood events recorded in the Minturn Formation.

Another possibility, however, is that storms formed locally within the CCB. If the Uncompahgre Uplift was in fact present, the length and width of the $\mathrm{CCB}$, based on our calculations, would have been great enough ( $>100 \mathrm{~km}$; Fig. 16) to produce the HCS beds in the prodelta unit. This assumes that winds existed to produce large waves on the east side of the basin. Given the low paleolatitude of the $\mathrm{CCB}$, the seaway likely would have been characterized by high sea-surface temperatures that could have caused large convective storms, like those in modern Southeast Asia. Wind speeds within the CCB also might have been amplified by orographic effects owing to the nearby mountain ranges. As with the hypothesis of monsoonal circulation described above, convective storms that formed within the CCB might have banked up against the Front Range and stalled, causing long-lived rainstorms and flooding.

\section{CONCLUSIONS}

The event beds of the Minturn Formation contain evidence for deposition under combined flows in proximal settings and unidirectional flows in distal settings. Like previous workers who studied event beds in the Sangre de Cristo and Eagle Valley areas, we propose that the unidirectional component of these flows is due to turbidity currents because the beds contain sole marks, sedimentary structures, and grading patterns common in turbidites, as well as consistent downslope-oriented paleocurrent indicators. In contrast to these previous studies, we propose that deposition in the more proximal parts of our study area often took place under combined oscillatory and unidirectional flows, as indicated by the presence of large-scale hummocky cross stratification, quasi-planar lamination, and combined-flow ripple lamination. The dynamic link to an active fan-delta shoreline resulted in proximal-to-distal lithofacies trends within the prodelta in which turbidite beds are proximally replaced by beds dominated by combined flows instead of complex and simple oscillatory flow. Thus, the more proximal prodelta sandstone event beds exhibit asymmetric HCS, unidirectional sole marks, and combined-flow ripple lamination, and lack isotropic HCS and 2D wave ripples.

The turbidite unit was deposited during a major transgression, and several lines of evidence indicate that both channels and interfluves in the underlying unconformity surface were flooded at this time. Mass-flow deposits at the base of the unit are stratigraphically linked to a change in paleocurrent directions, which likely reflects reorganization of prodelta drainage networks associated with slope failure. This reorganization took place early in the transgressive phase. Calculations based on the wavelength of large-scale HCS indicate that the fetch of the basin affected by storm-generated winds would have been at least $75 \mathrm{~km}$. The Central Colorado Basin (CCB) was situated at about $10^{\circ} \mathrm{N}$ latitude and was in the wind shadow of the ancestral Front Range, and hence easterly trade winds would not likely have produced large waves within the basin. Storms might have tracked into the CCB from the south, but in standard reconstructions the connection to the ocean to the south was very narrow through the Ouachita-Marathon suture zone. Instead, storms may have swept east from the Antler Mountain region across the Cordilleran Shelf to the northwest, a pathway consistent with summer monsoonal circulation patterns, which were beginning to dominate over zonal flow during the Pennsylvanian-Permian transition. Such storms would have crossed the Cordilleran seaway, would have been moisture laden, and if they stalled against the high Ancestral Rocky Mountains, would have resulted in both high wind speeds and flooding. A final possibility is that 


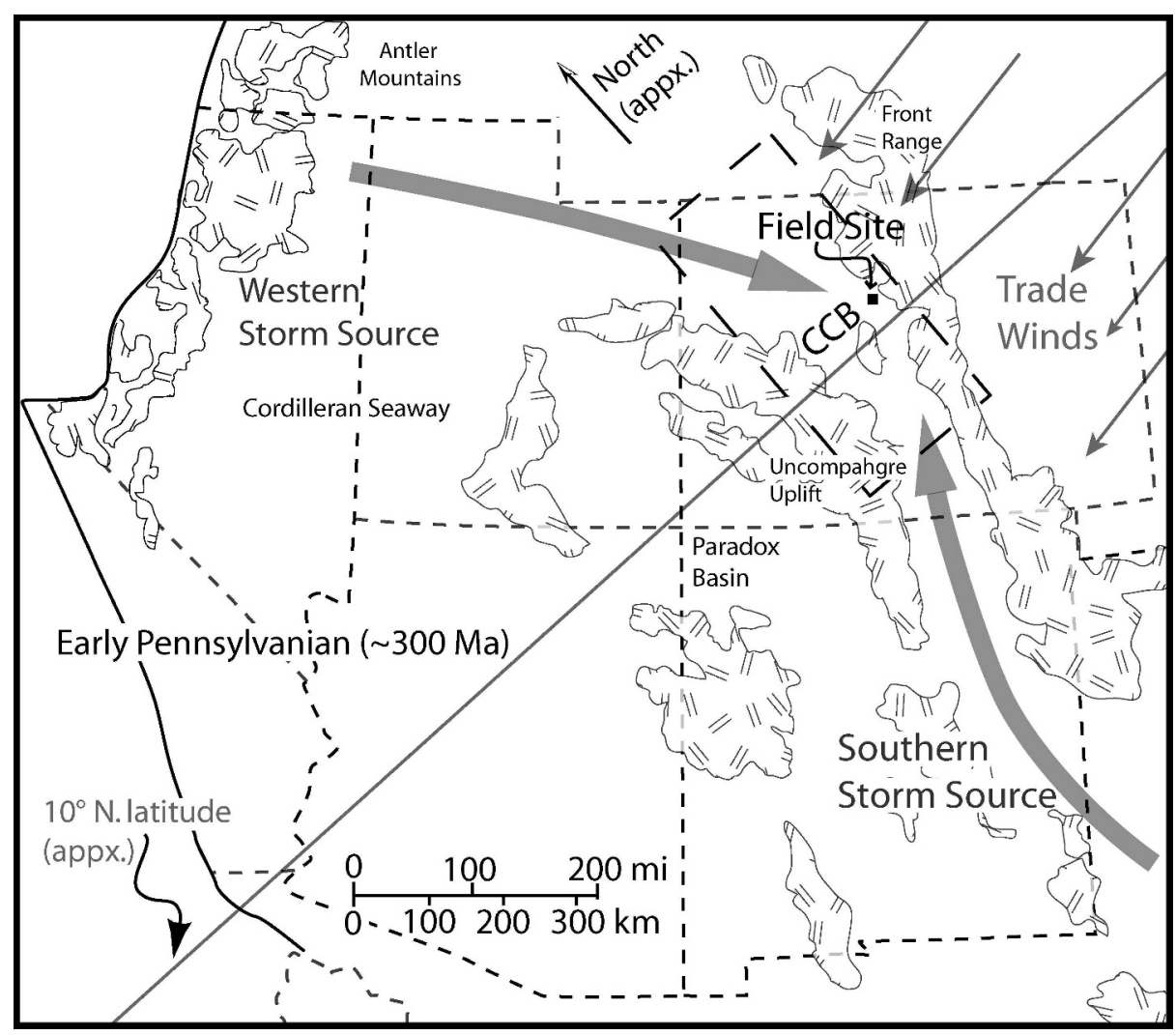

FIG. 16.-Paleogeographic map of the present-day southwest U.S. for the early Pennsylvanian. States are shown as dashed lines. The solid line on the left of map is the North American plate boundary. Modified from Johnson et al. (1992, their fig. 7B). This is a highstand sea-level reconstruction. Stippled masses are exposed land. The orientations of possible storm tracks are shown. The Ouachita-Marathon suture zone is to the south and west of the region shown.

high sea-surface temperatures at these low paleolatitudes may have led to large convective storms that developed within the CCB and also resulted in strong winds and floods.

\section{ACKNOWLEDGMENTS}

This project was funded by National Science Foundation Grants to Paul Myrow (EAR-0309693) at Colorado College and Jeff Parsons (EAR-0309887), Dept. of Oceanography, University of Washington. M.P. Lamb thanks Jeff Parsons for financial support and advisement during the course of this study. We are grateful to John Southard and David Mohrig for helpful discussions and suggestions. We also thank associate editor Paul McCarthy, as well as Gary Hampson and an anonymous reviewer, for their keen insight and suggestions.

\section{REFERENCES}

Aigner, T., 1982, Calcareous tempestites: storm dominated stratification in Upper Muschelkalk Limestones (Middle Trias, SW Germany), in Einsele, G., and Seilacher, A., eds., Cyclic and Event Stratification: Berlin, Springer-Verlag, p. 180-198.

Aigner, T., 1985, Storm Depositional Systems: New York, Springer-Verlag, Lecture Notes in Earth Sciences, v. 3, 174 p.

Arnold, C.A., 1941, Some Paleozoic plants from central Colorado and their stratigraphic significance: University of Michigan, Contributions to the Museum of Paleontology, v. 6, p. 59-70.

ARnotT, R.W., 1993, Quasi-planar-laminated sandstone beds of the Lower Cretaceous Bootlegger Member, north-central Montana: evidence of combined-flow sedimentation: Journal of Sedimentary Petrology, v. 63, p. 488-494.

ArnotT, R.W., and Southard, J.B., 1990, Exploratory flow-duct experiments on combined-flow bed configurations, and some implications for interpreting stormevent stratification: Journal of Sedimentary Petrology, v. 60, p. 211-219.

Blakey, R.C., Peterson, F., and Kocurek, G., 1988, Late Paleozoic and Mesozoic eolian deposits of the Western Interior of the United States: Sedimentary Geology, v. 56, p. $3-125$.

Crowell, J.C., 1978, Gondwanan glaciation, cyclothems, continental positioning, and climate change: American Journal of Science, v. 278, p. 1345-1372.

DeVoto, R.H., Bartleson, B.L., Schenk, C.J., and Waechter, N.B., 1986, Late Paleozoic stratigraphy and syndepositional tectonism, northwestern Colorado, in Stone, D.S., ed., New Interpretations of Northwest Colorado Geology: Rocky Mountain Association of Geologists, 1986 Symposium, p. 37-50.
Donner, H.F., 1949, Geology of the McCoy area, Eagle and Routt Counties, Colorado: Geological Society of America, Bulletin, v. 60, p. 1215-1248.

DotT, R.H., AND Bourgeols, J., 1982, Hummocky stratification: significance of its variable bedding sequences: Geological Society of America, Bulletin, v. 93, p. 663-680.

Duke, W.L., 1990, Geostrophic circulation or shallow marine turbidity currents? The dilemma of paleoflow patterns in storm-influenced prograding shoreline systems: Journal of Sedimentary Petrology, v. 60, p. 870-883.

Duke, W.L., Arnott, R.W.C., and Cheel, R.J., 1991, Shelf sandstones and hummocky cross-stratification: new insights on a stormy debate: Geology, v. 19, p. 625-628.

Dumas, S., Arnott, R.W.C., And Southard, J.B., 2005, Experiments on oscillatoryflow and combined-flow bed forms: implications for interpreting parts of the shallowmarine sedimentary record: Journal of Sedimentary Research, v. 75, p. 501-513.

Emanuel, K., 2003, Tropical cyclones: Annual Review of Earth and Planetary Sciences, v. 31 , p. $75-104$.

Gibbs, M.T., Rees, P.M., Kutzbach, J.E., Ziegler, A.M., Behling, P.J., and Rowley, D.B., 2002, Simulations of Permian climate and comparisons with climate-sensitive sediments: Journal of Geology, v. 110, p. 33-55.

Graber, H.C., And Madsen, O.S., 1988, A finite-depth wind-wave model, 1. Model description: Journal of Physical Oceanography, v. 18, p. 1465-1483.

Hamblin, A.P., AND Walker, R.G., 1979, Storm-dominated shallow marine deposits: the Fernie-Kootenany (Jurassic) transition, southern Rocky Mountains: Canadian Journal of Earth Sciences, v. 16, p. 1673-1690.

Hampton, M.A., 1972, The role of subaqueous debris flow in generating turbidity currents: Journal of Sedimentary Petrology, v. 72, p. 775-793.

Harms, J.C., Southard, J.B., Spearing, D.R., and Walker, R.G., 1975, Depositional environments as interpreted from primary sedimentary structures and stratification sequences: SEPM, Short Course Notes, no. 2, $161 \mathrm{p}$

Hasselmann, K.D., Ross, B., Muller, P., and Sell, W., 1976, A parametric wave prediction model: Journal of Physical Oceanography, v. 6, p. 200-228.

Heckel, P.H., 1986, Sea-level curve for Pennsylvanian eustatic marine transgressiveregressive depositional cycles along mid-continent outcrop belt, North America: Geology, v. 14, p. 30-334.

HoucK, K.J., 1991, Structural control on distribution of sedimentary facies in the Pennsylvanian Minturn Formation of north-central Colorado: U.S. Geological Survey, Bulletin, 1787-Y, 33 p

HoucK, K.J., 1993, Sedimentology and stratigraphy of the middle Minturn Formation (Pennsylvanian), McCoy Area, Eagle and Routt counties, Colorado [Unpublished Ph.D. thesis]: University of Colorado, $262 \mathrm{p}$.

Houck, K.J., 1997, Effects of sedimentation, tectonics, and glacio-eustasy on depositional sequences, Pennsylvanian Minturn Formation, north-central Colorado: American Association of Petroleum Geologists, Bulletin, v. 81, p. 1510-1533. 
Hoy, R.G., AND RidGway, K.D., 2002, Syndepositional thrust-related deformation and sedimentation in an Ancestral Rocky Mountains Basin, Central Colorado Trough, Colorado, USA: Geological Society of America, Bulletin, v. 114, p. 804-828.

Hoy, R.G., AND RIDGWAY, K.D., 2003, Sedimentology and sequence stratigraphy of fandelta and river-delta deposystems, Pennsylvanian Minturn Formation, Colorado: American Association of Petroleum Geologists, Bulletin, v. 87, p. 1169-1191.

Johnson, S.Y., Chan, M.A., and KonopKa, E.A., 1992, Pennsylvanian and Early Permian paleogeography of the Uinta-Piceance basin region, northwestern Colorado and northeastern Utah: U.S. Geological Survey, Bulletin 1787CC, 35 p.

Kairo, S., Suttner, L.J., And Prodip, P.K., 1993, Variability in sandstone composition as a function of depositional environment in coarse-grained delta systems, in Johnsson, M.J., and Basu, A., eds., Processes Controlling the Composition of Clastic Sediments: Geological Society of America, Special Paper 284, p. 263-282.

Komar, P.D., 1998. Beach Processes and Sedimentation: Upper Saddle River, New Jersey, Prentice Hall, 544 p.

KREISA, R.D., 1981, Storm-generated sedimentary structures in subtidal marine facies with examples from Middle and Upper Ordovician of southwestern Virginia: Journal of Sedimentary Petrology, v. 51, p. 823-848.

Lamb, M.P., Myrow, P.M., Lukens, C., Houck, K., and Strauss, J., 2008, Deposits from wave-influenced turbidity currents: Pennsylvanian Minturn Formation, Colorado, U.S.A.: Journal of Sedimentary Research, v. 78, p. xx-xx.

Lindsey, D.A., Clark, R.F., And Soulliere, S.J., 1986, Minturn and Sangre de Cristo formations of Southern Colorado: a prograding fan delta and alluvial fan sequence shed from the Ancestral Rocky Mountains, in Peterson, J.A., ed., Paleotectonics and Sedimentation in the Rocky Mountain region, United States: American Association of Petroleum Geologists, Memoir 41, p. 541-561.

Mallory, W.W., 1972, Regional synthesis of the Pennsylvanian System, in Mallory, W.W., ed., Geologic Atlas of the Rocky Mountain Region: Rocky Mountain Association of Geologists, p. 11-127.

MuldER, T., AND SYvitski, J.P.M., 1995, Turbidity currents generated at river mouths during exceptional discharges to the world oceans: Journal of Geology, v. 103, p 285-299.

Mulder, T., Syvitski, J.P.M., Migeon, S., Faugeres, J.C., and Savoye, B., 2003, Marine hyperpycnal flows: initiation, behavior and related deposits. a review: Marine and Petroleum Geology, v. 20, p. 861-882.

Myrow, P.M., 1992, Bypass-zone tempestite facies model and proximality trends for an ancient muddy shoreline and shelf: Journal of Sedimentary Petrology, v. 62, p. 99-115

Myrow, P.M., AND Hiscott, R.N., 1991, Shallow-water gravity-flow deposits, Chapel Island Formation, southeast Newfoundland, Canada: Sedimentology, v. 38, p. 935-959.

Myrow, P.M., Fischer, W., AND Goodge, J.W., 2002, Wave-modified turbidites: combined-flow shoreline and shelf deposits, Cambrian, Central Transantarctic Mountains: Journal of Sedimentary Research, v. 72, p. 641-656.

NitTrouer, C.A., AND Wright, L.D., 1994, Transport of particles across continental shelves: Reviews in Geophysics, v. 32, p. 85-113.

Nittrouer, C.A., Kuehl, S.A., Figueiredo, A.G., Allison, M.A., Sommerfield, C.K., Rine, J.M., Faria, E.C., AND Silveria, O.M., 1996, The geologic record preserved by Amazon shelf sedimentation: Continental Shelf Research, v. 16, p. 817-841.

PaOla, C., 2000, Quantitative models of sedimentary basing filling: Sedimentology, v. 47, p. $121-178$.

Parrish, J.T., 1993, Climate of the supercontinent Pangea: Journal of Geology, v. 101, p. 215-233.

Parrish, J.T., and Peterson, F., 1998, Wind directions predicted from global circulation models and wind directions determined from eolian sandstones of the western United States-A comparison: Sedimentary Geology, v. 56, p. 261-282.

Patzkowski, M.E., Smith, L.H., Markwich, P.J., Engberts, C.J., and Gyllenhall, E.D., 1991, Application of the Fujita-Zeigler paleoclimate model: Early Permian and Late Cretaceous examples: Palaeogeography, Palaeoclimatology, Palaeoecology, v. 86, p. 67-85.

Peterson, F., 1998, Pennsylvanian to Jurassic eolian transportation systems in the western United States: Sedimentary Geology, v. 56, p. 207-260.

Pirmez, C., Pratson, L.F., and Steckler, M.S., 1998, Clinoform development by advection-diffusion of suspended sediment: modeling and comparison to natura systems: Journal of Geophysical Research, v. 103, p. 24,141-24,157.
Posamentier, H.W., And Allen, G.P., 1999, Siliciclastic Sequence Stratigraphy: Concepts and Applications: SEPM, Concepts in Sedimentology and Paleontology, v. 9, $210 \mathrm{p}$.

Ross, C.A., AND Ross, J.R.P., 1987, Late Paleozoic sea levels and depositional sequences, in Ross, C.A., and Haman, D., eds., Timing and depositional history of eustatic sequences: constraints on seismic stratigraphy: Cushman Foundation for Foraminiferal Research, Special Publication 24, p. 137-149.

Rowe, C.M., Loope, D.B., Oglesby, R.J., Van Der Voo, R., and Broadwater, C.E., 2007, Inconsistencies between Pangean reconstructions and basic climate controls: Science, v. 318, p. 1284-1286.

SCHENK, C.J., 1986, Turbidites in the lower part of the Eagle Valley Evaporite, Eagle County, Colorado, and implications for Desmoinesian paleogeography: Rocky Mountain Association of Geologists, 1986 Symposium, p. 123-128.

Schenk, C.J., 1989, Sedimentology and stratigraphy of the Eagle Valley Evaporite (middle Pennsylvanian), Eagle Basin, Northwest Colorado [Unpublished Ph.D thesis]: University of Colorado, $172 \mathrm{p}$.

Soreghan, G.S., Elmore, R.D., and Lewchuk, M.T., 2002b, Sedimentologicalmagnetic record of western Pangean climate in upper Paleozoic loessite (lower Cutler beds, Utah): Geological Society of America, Bulletin, v. 114, p. 1019-1035.

Soreghan, M.J., Soreghan, G.S., and Hamilton, M.A., 2002a, Paleowind inferred from detrital-zircon geochronology of upper Paleozoic loessite, western equatorial Pangea: Geology, v. 30, p. 695-698.

Soulliere, S.J., De Angelis, B.L., And Lindsey, D.A., 1984, Miscellaneous Field Studies Map: U.S. Geological Survey: Reston, Virginia.

Southard, J.B., Lambie, J.M., Federico, D.C., Pile, H.T., and Weidman, C.R., 1990, Experiments on bed configurations in fine sands under bidirectional purely oscillatory flow, and the origin of hummocky cross-stratification: Journal of Sedimentary Petrology, v. 60, p. 1-17.

Stevens, C.H., 1958, Stratigraphy and paleontology of the McCoy, Colorado, Area [Unpublished M.A. thesis]: University of Colorado, $242 \mathrm{p}$

Sun, T., Paola, C., And Parker, G., 2002, Fluvial fan deltas: Linking channel processes with large-scale morphodynamics: Water Resources Research, v. 38, p. 26-1-26-10.

Swenson, J.B., Paola, C., Pratson, L., Voller, V.R., and Murray, A.B., 2005, Fluvia and marine controls on combined subaerial and subaqueous delta progradation: morphodynamic modeling of compound clinoform development: Journal of Geophysical Research, v. 110, no. F02013, p. 1-16, doi: 10.1029/2004JF000265.

TABor, N.J., AND Montañez, I.P., 2002, Shifts in late Paleozoic atmospheric circulation over western equatorial Pangea: insights from pedogenic mineral $\delta^{18} \mathrm{O}$ composition: Geology, v. 30, p. 1127-1130.

Tweto, O., 1949, Stratigraphy of the Pando area, Eagle County, Colorado: Colorado Scientific Society, Proceedings, v. 15, p. 149-235.

Tweto, O., And Lovering, T.S., 1977, Geology of the Minturn Formation 15-minute quadrangle, Eagle and Summit Counties, Colorado: U.S. Geological Survey, Professional Paper 956, $96 \mathrm{p}$.

Walker, R.G., 1984, Shelf and shallow marine sands, in Walker, R.G., ed., Facies Models: Geoscience Canada, Reprint Series 1, p. 141-170.

WiLSON, J.L., 1967, Cyclic and reciprocal sedimentation in Virgillian strata of southern New Mexico: Geological Society of America, Bulletin, v. 78, p. 805-817.

Wright, M.E., and Walker, R.G., 1982, Cardium Formation at Seebe, Albertastorm-transported sandstones and conglomerates: American Association of Petroleum Geologists, Bulletin, v. 66, p. 644-645.

YANG, B., Dalrymple, R.W., AND Chun, S., 2006, The significance of hummocky crossstratification (HCS) wavelengths: evidence from an open-coast tidal flat, South Korea: Journal of Sedimentary Research, v. 76, p. 2-8.

YoKoKawa, M., 1995, Combined-flow ripples: genetic experiments and applications for geologic records: Kyushu University, Faculty of Science, Memoirs, Series D, Earth and Planetary Sciences, v. 29, p. 1-38.

Yokokawa, M., Masuda, F., and Endo, N., 1995, Sand particle movement on migrating combined-flow ripples: Journal of Sedimentary Research, v. 65, p. 40-44.

Received 11 September 2007; accepted 24 February 2008 